\title{
Palynological Study of Carbonated Mounds during the Holocene along the Atlantic and Mediterranean Moroccan Margins
}

\author{
Jihad Rachid ${ }^{\mathrm{a}, *}$, Touria Hssaida ${ }^{\mathrm{a}}$, Naima Hamoumi ${ }^{\mathrm{b}}$, Loubna Terhzaz ${ }^{\mathrm{b}}$, Silvia Spezzaferri ${ }^{\mathrm{c}}$, \\ Norbert Frank ${ }^{\mathrm{d}}$, Lamia Daghor ${ }^{\mathrm{e}}$ \\ ${ }^{a}$ Hassan II University, Laboratory dynamics of sedimentary basins and geological correlations, Faculty of Sciences Ben M'Sick Casablanca, Morocco \\ ${ }^{\mathrm{b}}$ Mohammed V University, Research Group ODYSSEE Laboratory Materials, Nanotechnology and Environment (LMNE), Research Center for Materials Science, Faculty of Sciences Rabat, \\ Morocco ${ }^{\mathrm{C}}$ University of Fribourg, Dpt. Geosciences, B.1700 Fribourg, Switzerland \\ ${ }^{\mathrm{d}}$ Heidelberg University, Institute of Environmental Physics and Institute for Geosciences, Heidelberg, Braden-Württemberg, Germany \\ e Laboratory of Ecology and Environment, Department of Biology, Faculty of Sciences Ben M'sik, Hassan II University of Casablanca, B.P. 7955, Sidi Othmane, Casablanca, Morocco
}

Keywords:

Palynology

Dinoflagellate cysts

Carbonated mound

Holocene

Atlantic and Mediterranean Moroccan margins

\section{A B S T R A C T}

A palynological study of carbonate mounds of Atlantic and Mediterranean Moroccan margins was conducted on sediment boxcores MD13-3441, MD13-3456, MD13-3461, MD13-3465, MD13-3468 collected during the oceanographic cruise MD 194/Eurofleet - GATEWAY, which took place on June 2013.

The organic remaining revealed a dominance of dinoflagellate cysts over the continental fraction, which showed very low rates. The use of pollen data, despite their low representativity, is proving to be a valuable tool for the paleoclimate interpretation.

The palynological quantitative and qualitative analysis revealed the evolution of the paleoenvironment and climate change of the carbonate mounds during this study interval. The terminal Pleistocene-basal Holocene passage highlighted by the dominance of cold taxa of dinoflagellate cysts. The presence and dominance of tree and shrub pollen coupled by the presence of altitudinal conifers confirmed a cold climate in both continental and marine environments.

During the lower-middle Holocene, the variations in the relative frequencies of dinoflagellate cyst associations reflect the evolution of the paleoenvironment from inner neritic to oceanic.

The recorded microflora shows a cyclicity during the lower Holocene from arid to semi-arid between 10.07 and $9.85 \mathrm{ka}$ (the abundance of herbaceous and steppe), to become arid again around ( $9.69 \mathrm{ka}$ ) by the consistently high rate of herbaceous and steppe.

In contrast, the paleoclimate recorded during the Middle Holocene is semi-humid to $6.29 \mathrm{ka}$ (high rate of trees and shrubs) and evolves to a warm dry climate at 5.9-5.14 ka, reflected by the abundance of herbaceous and steppe.

\section{Introduction}

Since their discover along the European Atlantic margins, cold-water carbonate mounds stimulated the interest of many researchers.

Cold water coral mounds along the Moroccan Atlantic margin (Gulf of Cadiz) were discovered for the first time during the oceanographic

\footnotetext{
* Corresponding author.

E-mail addresses: rachidjihad231@gmail.com (J. Rachid), touria.hssaida@gmail.com (T. Hssaida),naimahamoumi5@gmail.com (N. Hamoumi), loubna.terhzaz@gmail.com (L. Terhzaz), silvia.spezzaferri@unifr.ch (S. Spezzaferri),

norbert.Frank@iup.uni-heidelberg.de (N. Frank), l.daghor@gmail.com (L. Daghor).
}

cruise CADIPOR I Belgica 02/12 in 2002 (Van Rooij et al., 2002) and along the Moroccan margin of the Eastern Mediterranean (Alboran Sea), during the oceanographic cruise R/V Hesperides in 2006 (Comas and Pinheiro, 2007).

The Beta carbonate mound on the Moroccan North Atlantic margin was investigated for sedimentology and stable isotope (oxygen and carbon) by De Mol et al. (2011, 2012), Terhzaz (2019), Fink et al. (2013), Titschack et al. (2016) and Terhzaz et al. (2018) studied the sedimentology and geochemistry of the sediments recovered on the Brittlestar I ridge and Cabliers Mound along the Moroccan Mediterranean margin. Benthic foraminiferal and ostracod assemblages were related to the circulation patterns and marine productivity in the Alboran Sea (Fink et al., 2013; Stalder et al., 2015, 2018, 2019). Age constrain for corals, benthic 
foraminifera and associated fauna through time was proved by Aguilar et al. (2013), Fink et al. (2013) and Stalder et al. (2015, 2018, 2019).

A palynological (pollen and dinoflagellate) investigation to reconstruct the impact of marine and terrestrial climate changes on carbonate mounds and cold-water corals ecosystem was missing until now.

Dinoflagellates are planktonic organisms include that can be divided into autotrophic, using only photosynthesis and heterotrophic using different energy sources. Autotrophic dinoflagellates have latitudinal distribution (Wall et al., 1977; Harland, 1983; Edwards and Andrle, 1992) which is controlled by temperature and salinity of surface waters, marine circulation patterns and nutrient supply (Dale, 1976; Eynaud et al., 2004; Harland, 1983; Morzadec-Kerfourn, 1988; Taylor and Pollingher, 1987; Turon et al., 2003; Wall et al., 1977; Zonneveld et al., 2013). They are generally used as an indirect measure of primary productivity of ocean waters (Turon and Londeix, 1988; Devillers and de Vernal, 2000). Their cysts have proven to be excellent bioclimatic tracers in the Quaternary (Turon, 1984).

This research is part of the international programs "Cold-water carbonate mounds in shallow and Deep Time" (COCARDE). It presents the results of the palynological study of Box cores: MD13-3441, MD13-3456, MD13-3461, MD13-3465 and MD13-3468 retrieved in the North Atlantic off Morocco (Gulf of Cadiz) and the Alboran Sea on the Brittle Star I ride off Melilla during the oceanographic cruise MD 194, EURO Fleet Gateway-TORE aboard the N / O Marion Dufresne held from 10 to 21 June 2013.

\section{Geological setting, geodynamic and oceanographic}

\subsection{Geological setting}

The Gulf of Cadiz is located in the northeastern part of the Atlantic Ocean between Africa and Europe, between $37^{\circ}$ parallel North and $34^{\circ}$ latitude south and between meridians $6^{\circ}$ and $9^{\circ}$ West. It extends west of the Gibraltar Strait to the south of Cape St. Vincent, along the Portuguese and Spanish margins (Mulder et al., 2002, 2003; Hanquiez, 2006; Marchès et al., 2007; Hanquiez et al., 2010). This complex geological setting is bounded to the north by the transform fault AzoresGibraltar and to the east by the arc of Gibraltar (Maldonado et al., 1999; Medialdea et al., 2004, 2009; Zitellini et al., 2009).

It evolved from passive margin into an active margin from the Mesozoic to the early Cenozoic, then into a fore arc during the lower Miocene and finally to a passive margin with a subsiding basin in the late Miocene (Maldonado and Nelson, 1999).

Tectonic activity is responsible for the irregular topography of the seafloor in this region, characterized by banks, diapirs, ridges and mud volcanoes (Maldonado et al., 1999; Kenyon et al., 2000). Locally coldwater carbonate mounds hosting cold-water corals are also present in this region (De Mol et al., 2012).

The Alboran Sea is the western part of the Mediterranean Sea, it has a maximum depth of $2 \mathrm{~km}$, a length of $400 \mathrm{~km}$ and a maximum width of $200 \mathrm{~km}$. It is limited to the north by the Betic Chain of Spain, to the south by the Rif Mountains in Morocco and Tell Algeria Chain, to the west by the Strait of Gibraltar and to the east by the line connecting Cape Figalo in Algeria in the Cabo de Gata in Spain (Carter et al., 1972).

The Moroccan Alboran margin consists of a continental shelf (0-200 $\mathrm{m}$ depth) rather narrow, with a width around $5 \mathrm{~km}$ opposite to the three Forks Cape, around $16 \mathrm{~km}$ from its central portion, opposite to the Bay of Nador. This platform shows a gentle and regular slope with isobaths parallel to the shore between 0 and $45 \mathrm{~m}$, but it ends with a sharp slope towards the south Alboran basin (Tesson and Gensous, 1979).

The tectonic setting of the Alboran basin results from the postMessinian deformation. In the Holocene, the transtensive tectonics has generated new depocentres and transpressional tectonics has generated local uplifting positive structures such as the Alboran Ridge (Comas et al., 1999). The evolution of the Alboran basin is characterized by the accumulation of sediments and a calc-alkaline to alkaline magmatism (Comas et al., 1999). The Alboran Sea shows a complex topography with several sub-basins, ridges, banks and mounds.

\subsection{Oceanographic setting}

The present day oceanographic circulation in the Gulf of Cadiz is controlled by the exchange of water through the Strait of Gibraltar. Surface Atlantic water masses (AIW) flow into the Alboran Sea, and the deep water Mediterranean masses (MOW) flow into the Atlantic Ocean (Lacombe and Lxzeray, 1959; Ochoa and Bray, 1991; Nelson et al., 1999; Hanquiez, 2006).

Five water masses characterize the southern Gulf of Cadiz: the North Atlantic surface waters between 0 and $200 \mathrm{~m}$, the North Atlantic central water masses between 200 and $600 \mathrm{~m}$, the intermediate Antarctic waters masses between 600 and $1500 \mathrm{~m}$. Mediterranean waters flow at around $1000 \mathrm{~m}$ of water depth and the deep North Atlantic masses waters flow below 1500 m (Machín et al., 2006; Ambar et al., 2008; Louarn and Morin, 2011).

The Alboran basin is a transition region between two water bodies: the Atlantic Ocean and the Mediterranean Sea. Four water masses can be identified in the Alboran Sea: the Atlantic Water (AW) from the surface to $150 \mathrm{~m}$ of water depth, the Atlantic modified water (MAW) at 150-200 m water depth flow through the Strait of Gibraltar to the Algeria Basin; the Levantine intermediate water (LIW) flow between 200 and $600 \mathrm{~m}$, are formed in the eastern Mediterranean Sea and the flow west to the Atlantic Ocean; the West Mediterranean deep water (WMDWs) are present below the LIW formed in the Gulf of Lions in the northern part of the West Mediterranean Sea (Benzohra and Millot, 1995).

Two semi-permanent gyres (eddies) are formed after the inlet of North Atlantic Water Surface through the Strait of Gibraltar and their development is controlled by several factors such as atmospheric pressure, temperature, salinity (Heburn and La Violette, 1990; Vargas-Yáñez et al., 2002).

\subsection{Climate context}

The present climate along the Moroccan North Atlantic margin is oceanic and temperate; it is sub-humid, with hot and cool Summers, and cold and humid Winters according to the index of Martonne. The climate in the Moroccan Mediterranean margin is typically Mediterranean with contrasting seasons and local microclimates influenced by altitude and Saharian influences. According to the index of Martonne, it is semiarid temperate or warm winter (Barathon, 1987b; Bouslam, 1989). The dominant wind directions is SW in Summer and WSW in Winter (Barathon, 1987a) sometimes characterized by violent storms.

During the Quaternary, these regions experienced glacial and interglacial cycles that have resulted in the alternation of arid and humid periods with abrupt transitions on the continent (Biberson, 1971; Wengler et al., 1992; Linstädter and Zielhofer, 2010).

\section{Palynological analysis of sediments associated with carbonates mounds}

\subsection{Material and method}

The studied sediments collected during the oceanographic cruise MD 194 EURO GATEWAY Fleet aboard the R/V Marion Dufresne, which took place from June, 10 to June 21, 2013 in the Atlantic and Mediterranean Moroccan margins (Fig. 1, Table 1).The carbonate mounds sampled are:

- Beta mound (MD13-3441) in the North Atlantic Moroccan margin at $35^{\circ} 17.765^{\prime} \mathrm{N}, 6^{\circ} 47.276^{\prime} \mathrm{W}$ and $532 \mathrm{~m}$ of water depth,

- Brittlestar I Ride is (MD13-3456) in the Mediterranean Moroccan 


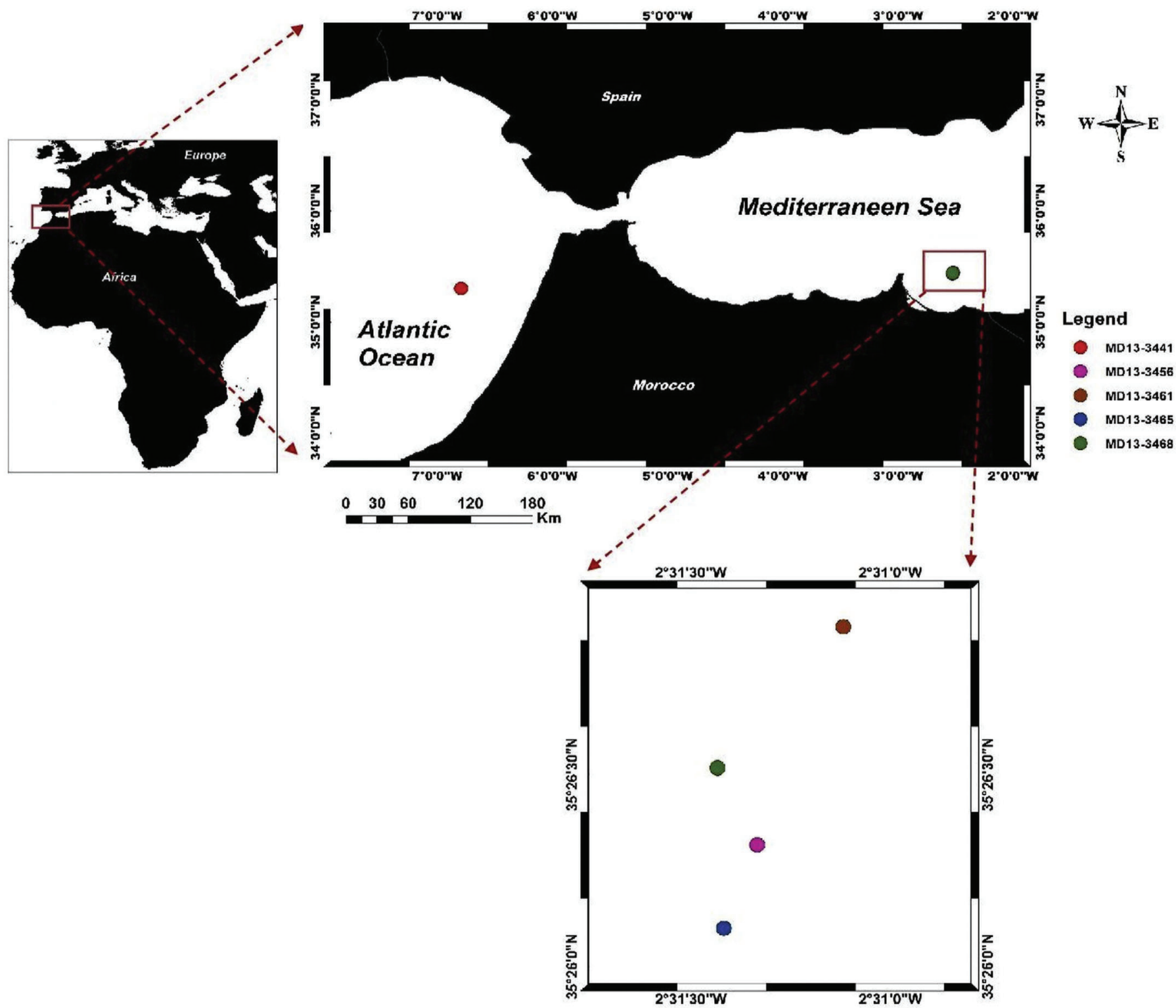

Fig. 1. Location of the studied cores (Table 1) in the Western Mediterranean and North-West Atlantic.

Table 1

General and geographical information concerning the 5boxcores of this study.

\begin{tabular}{|c|c|c|c|c|}
\hline Mound & Location & Latitude $\left({ }^{\circ} \mathrm{N}\right)$ & Longitude $\left({ }^{\circ} \mathrm{W}\right)$ & Water depth (m) \\
\hline Beta mound (MD13-3441) & Gulf of Cadiz & $35^{\circ} 17,75$ & $6^{\circ} 47,28$ & -503 \\
\hline Brittlestar I Ride (MD13-3456) & Alboran Sea & $35^{\circ} 26,19$ & $2^{\circ} 30,80$ & -330 \\
\hline Brittlestar I Ride Summit (MD13-3461) & Alboran Sea & $35^{\circ} 26,53$ & $2^{\circ} 31,07$ & -320 \\
\hline Brittlestar I Ride West (MD13-3465) & Alboran Sea & $35^{\circ} 26,06$ & $2^{\circ} 30,85$ & -346 \\
\hline Near the Brittlestar I ride (MD13-3468) & Alboran Sea & $35^{\circ} 25,91$ & $2^{\circ} 30,86$ & -470 \\
\hline
\end{tabular}

margin at $35^{\circ} 26.19 \mathrm{~N}, 30.80 \mathrm{~W} 2$ and $330 \mathrm{~m}$ of water depth,

- Brittlestar I Ride Summit (MD13-3461) in the Mediterranean Moroccan margin at $35^{\circ} 26.53 \mathrm{~N}, 31.07 \mathrm{~W} 2$ and $320 \mathrm{~m}$ of water depth, - Brittlestar I Ride West (MD13-3465) in the Mediterranean Moroccan margin at $35^{\circ} 26.06 \mathrm{~N}, 30.85 \mathrm{~W} 2$ and $346 \mathrm{~m}$ of water depth,

- Near the Brittlestar I ride (MD13-3468) in the Mediterranean Moroccan margin at $35^{\circ} 25.91 \mathrm{~N}, 30.86^{\circ} 2$ and $470 \mathrm{~W}$ m water depth.
Twenty-eight samples were collected from different sediment types according to the shipboard description of box cores (Van Rooij et al., 2013). They were investigated for their palynological content in the laboratory of Micropaleontological analysis at the Faculty of Sciences Ben M'sik, Casablanca, according to the standard method requiring a chemical treatment with $\mathrm{HCl}(10 \%)$ and $\mathrm{HF}$ (40\%) (for $24 \mathrm{~h}$ ), sieving at $10 \mu \mathrm{m}$ and mounting the organic residue on the smear slide. 
Palynofacies were reconstituted based on assemblage composition: organic microfossils (pollen, spores, organic remains of foraminifera after the dissolution of the calcitic test, dinoflagellate, acritarchs) and algae. All palynomorphs were counted, but only dinoflagellate cysts, which are a reliable tool for reconstructions of Quaternary marine paleoenvironments, were counted at specific level. Specimen counting was performed using a Leica microscope with a natural light X40 magnification. Two hundred individuals were identified and counted per each slide to obtain statistically valid results. Less abundant and/or accessory species were also considered to evaluate biodiversity.

\subsection{Results}

\subsubsection{The Moroccan Atlantic margin}

3.2.1.1. Box coreMD13-3441(from base to top):. Box core MD 13-3441 contains $90 \mathrm{~cm}$ of sediments. From the base to $85 \mathrm{~cm}$ they consist of brownish to grayish micritic mud, $85-65 \mathrm{~cm}$ and $55-35 \mathrm{~cm}$ contain brownish to grayish muddy micrite, $65-55 \mathrm{~cm}$ consist of brownish to grayish micritic mud, $35-25 \mathrm{~cm}$ and $15-0 \mathrm{~cm}$ contain of brownish to grayish muddy allochem limestones and from 25 to $15 \mathrm{~cm}$ consist of grayish allochemic mud (Terhzaz, 2019).

Eleven samples were processed for this box core. Their age span the interval between 12.09 and 6.8 ka before the present (Fig. 2) based on the age of the surrounding coral (Schröder-Ritzrau et al., 2015). Samples 90-75 cm correspond to the late Pleistocene/Tarentian (12.09-11.7 ka), from 75 to $25 \mathrm{~cm}$ to the lower Holocene/Greenlandian (11.70-10.9 ka), $25-15 \mathrm{~cm}$ in the middle Holocene/Northgrippian (10.84-7.43 ka) and above $15 \mathrm{~cm}$ surface the middle Holocene/Northgrippian
(7.43-6.8 ka). The stratigraphic placement takes into account the recent ratification of these stages and their limits by the International Subcommission on Quaternary Stratigraphy (ISQS) (a subcommission of the International Commission on Stratigraphy - ICS) being set Cambridge on June 19, 2018. At 11,700 (before AD 2000). Tarentian/Greelandian, 8326(before AD 2000).Greelandian/Northgrippian 4250 (before AD 2000), Northgrippian/Meghalayian.(Walker et al., 2018).

The palynological analysis of the core shows three dinoflagellate cyst assemblages that have paleoecological significance as is illustrated by Fig. 2, 3 and Plate I:

- Between 90 and $75 \mathrm{~cm}$, dinoflagellate cysts dominate other organic microfossils (spores, pollen grains, foraminifera chitinous) (75-83\%). Within this interval, autotrophic cysts dominate (93-100\%) with respect to heterotrophic cysts. The inner neritic cyst Lingulodinium machaerophorum is dominant (27 and 40\%). Inner neritic cysts of the genus Spiniferites (S. bentorii, S. bulloideus, S. membranaceus, S. hyperacanthus and S. septentrionalis) represent the $5-10 \%$ of the entire assemblage. Note Spiniferites lazus is present with relatively high percentages from 5 to 7\%. The oceanic genus Impagidinium, represented by the species I. patulum (4-5\%), I. sphaericum I. paradoxum (4-5\%) and I. aculeatum( $0-2 \%)$.

- Between 75 and $15 \mathrm{~cm}$, Lingulodinium machaerophorum is still high reaching $41 \%$. Among the external neritic and oceanic species, Spiniferites lazus disappear, Impagidinium sphaericum and Nematosphaeropsis labyrinthus (3\%) decrease in abundance, and remarkable presence of Spiniferites mirabilis (30\%) and Impagidinium aculeatum (20\%). Heterotrophic dinoflagellates develop during this interval: Multispinula quanta, (11 and 16\%), the genus Brigantedinium ( $B$. caracoense, B. irregulare, B.simplex, B. asymmetricum and Brigantedinium

MD 13-34 41- The Moroccan Atlantic margin (Gulf of Cadiz)

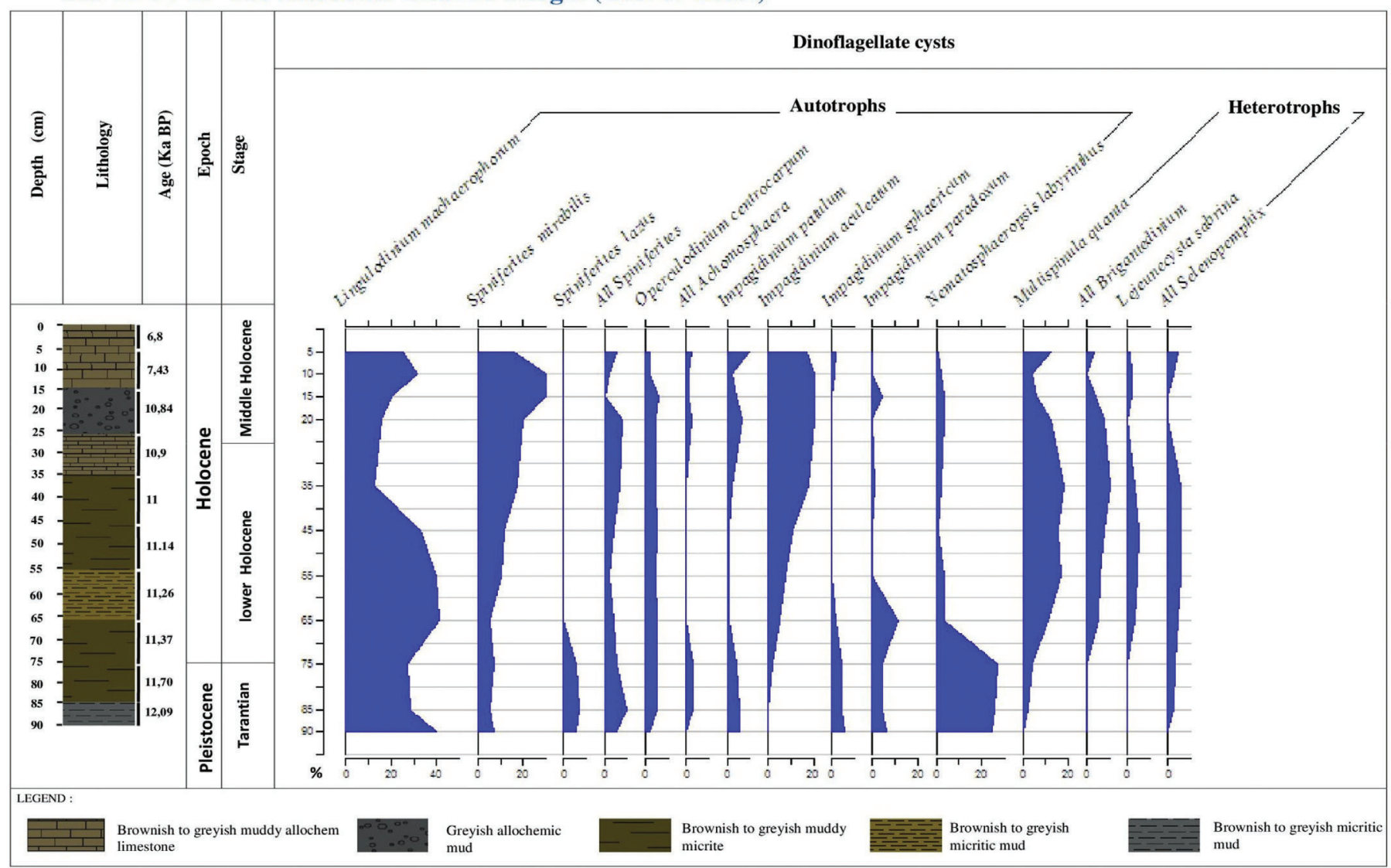

Fig. 2. Chart illustrating the total count and diversity of the marine palynomorphs, vertical stratigraphic distribution of the recorded dinoflagellate cysts per number of cysts counted;in the boxcore MD 13-3441. Age: Coral age (Schröder-Ritzrau et al., 2015), lithofacies: (Terhzaz, 2019). 
ssp from 5 to $10 \%$, Lejeunacysta sabrina, between 0 and $5 \%$ and the genus Selenopemphix between 0 and 5\%.

- Between $15 \mathrm{~cm}$ and the surface, autotrophic taxa reach the 80-92\%. Lingulodinium machaerophorum remains abundant but is still below the values reached at the base of the previous interval. Additionally, Spiniferites mirabilis and Impagidinium aculeatum reach 30 and 20\%, respectively. Operculodinium centrocarpum is consistently present with values of $4-6 \%$ in previous intervals and decrease in abundance towards the sediment surface (2\%). Heterotrophic taxa represented by Multispinula quanta (12\%), Brigantedinium (B. cariacoense, B. irregulare, B. simplex, B. asymmetricum and Brigantedinium spp.) display values fluctuating between 0 and 4\%, Lejeunacysta sabrina between 1 and $2 \%$ and Selenopemphix reaches up to $4 \%$.

\subsubsection{Moroccan Mediterranean margin}

3.2.2.1. The box core MD13-3465 :. The MD13-3465 boxcore is $60 \mathrm{~cm}$ long. Sediments consist of grayish to olive green micritic mud between the base up to $5 \mathrm{~cm}$ and brownish muddy allochemic limestone from $5 \mathrm{~cm}$ to the surface (Terhzaz et al., 2018). The estimated age of the sediments is $9.85 \mathrm{ka}$ at the base and $9.69 \mathrm{ka}$ at the top (Terhzaz et al., 2018). Sediments, therefore, belong to the middle Holocene/Northgrippian. Four samples were analyzed between $30 \mathrm{~cm}$ and the surface

The distribution of dinoflagellate cysts is relatively homogeneous. The percentage of autotrophic taxa increases from bottom to top, from 47 to $71 \%$. Among them, the cyst typically of internal neritic environment Lingulodinium machaerophorum varies between 10 and 19\%. Among neritic Operculodinium centrocarpum cysts have a homogeneous distribution in the core, between 2 and 5\%. The genus Spiniferites is represented by the species S.bulloïdeus, S. bentorii, S. membranaceus, S. septentrionalis and Spiniferites spp. showing values from 2 to $7 \%$, and by $S$. mirabilis, which is the dominant species. It increases in abundance from $5 \%$ at the base, to $35 \%$ at the top of the sedimentary sequence. Nematospaheropsis labyrinthus is constantly present but its abundance never exceeds 3\%. The oceanic taxa Impagidinium aculeatum increases in abundance from the base (5\%) to the top (15\%). Impagidinium paradoxum is also present and I. sphaericum is rare. The percentage of heterotrophic taxa decreases towards the top; they are represented in particular by Multispinula qunta (5-19\%), Polykrikos kofoïdii (10-17\%) and Brigantedinium spp. (5-6\%). (Figs. 4, 5 and Plate I)

3.2.2.2. The box core MD13-3456:. The MD13-3456 box core spans $80 \mathrm{~cm}$ of sediments. From the base up to $10 \mathrm{~cm}$ they consist of gray micritic mud, the top most $10 \mathrm{~cm}$ consists of brownish mud (Terhzaz et al., 2018). The age of the sediment was estimated by (Terhzaz et al., 2018) taking into account 500 years between the age of the corals and the surrounding sediment proposed by Stalder et al. (2015). The age of the sample taken from the base to $60 \mathrm{~cm}$ was estimated $5.9 \mathrm{ka}$ and the samples above, between 10 and $0 \mathrm{~cm}$ estimated $5.45 \mathrm{ka}$. Five samples were taken in this core including two samples from 10 to $0 \mathrm{~cm}$. They belong to the middle Holocene (Northgrippien) (Walker et al., 2018)

Dinoflagellate assemblages are relatively homogeneous; both heterotrophic and autotrophic taxa display values fluctuating from 42 to $59 \%$, respectively. Lingulodinium machaerophorum, a taxon characteristic of the inner neritic zone shows values from 9 to $19 \%$, with a slight

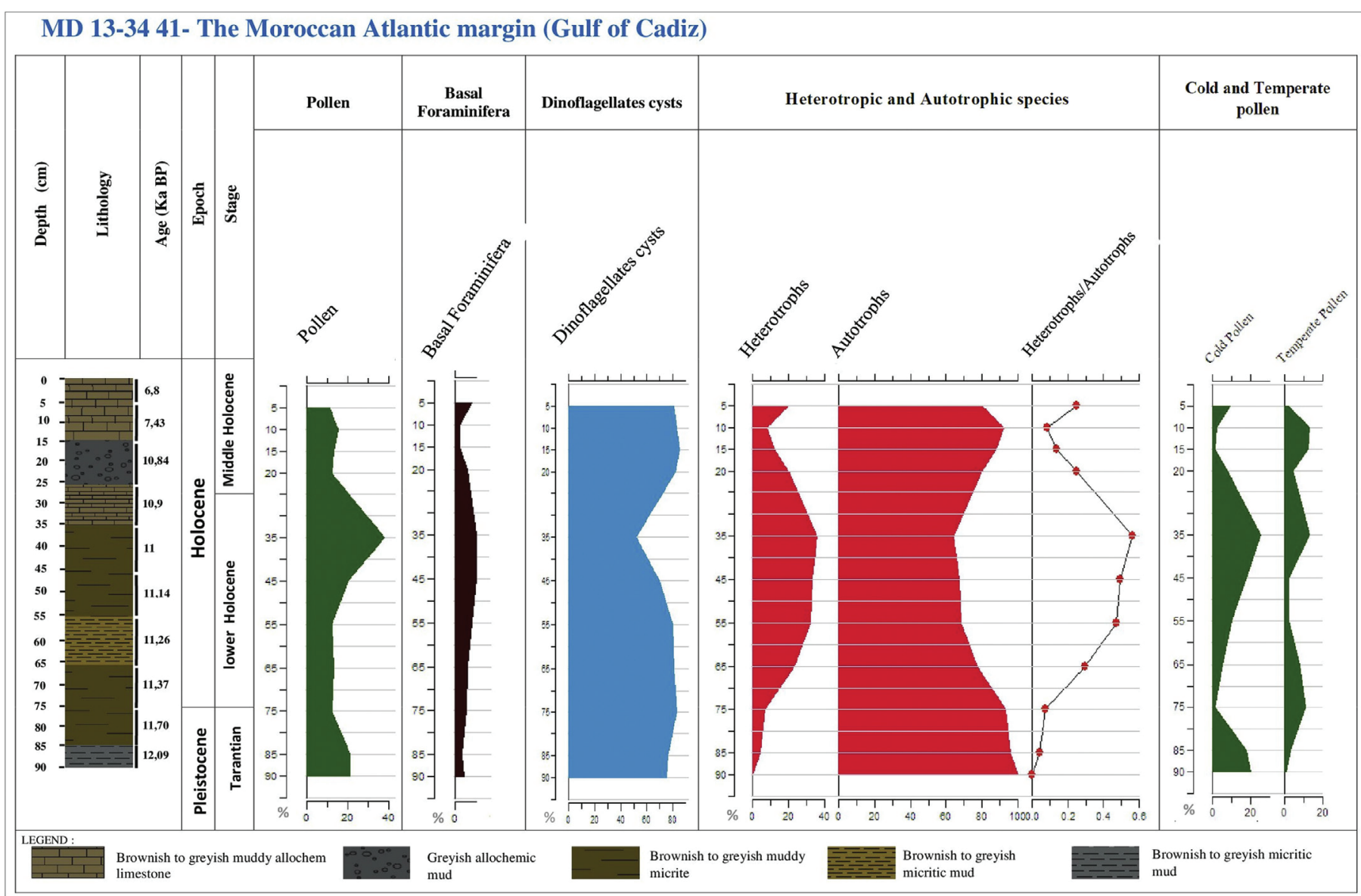

Fig. 3. Chart illustrating the total count and diversity of the marine and terrestrial palynomorphs, vertical stratigraphic distribution of the recorded pollen, basal foraminifera, Dinoflagellates cysts (total number) compared to all the palynological content, Heterotrophic and autotrophic species with the ratio (Heterotrophic/Autotrophic) per number of cysts counted and cold and temperate pollen per number of pollen counted in the boxcore MD 13-3441. 


\section{13-34 65 - The Moroccan Mediterranean margin (Alboran Sea)}

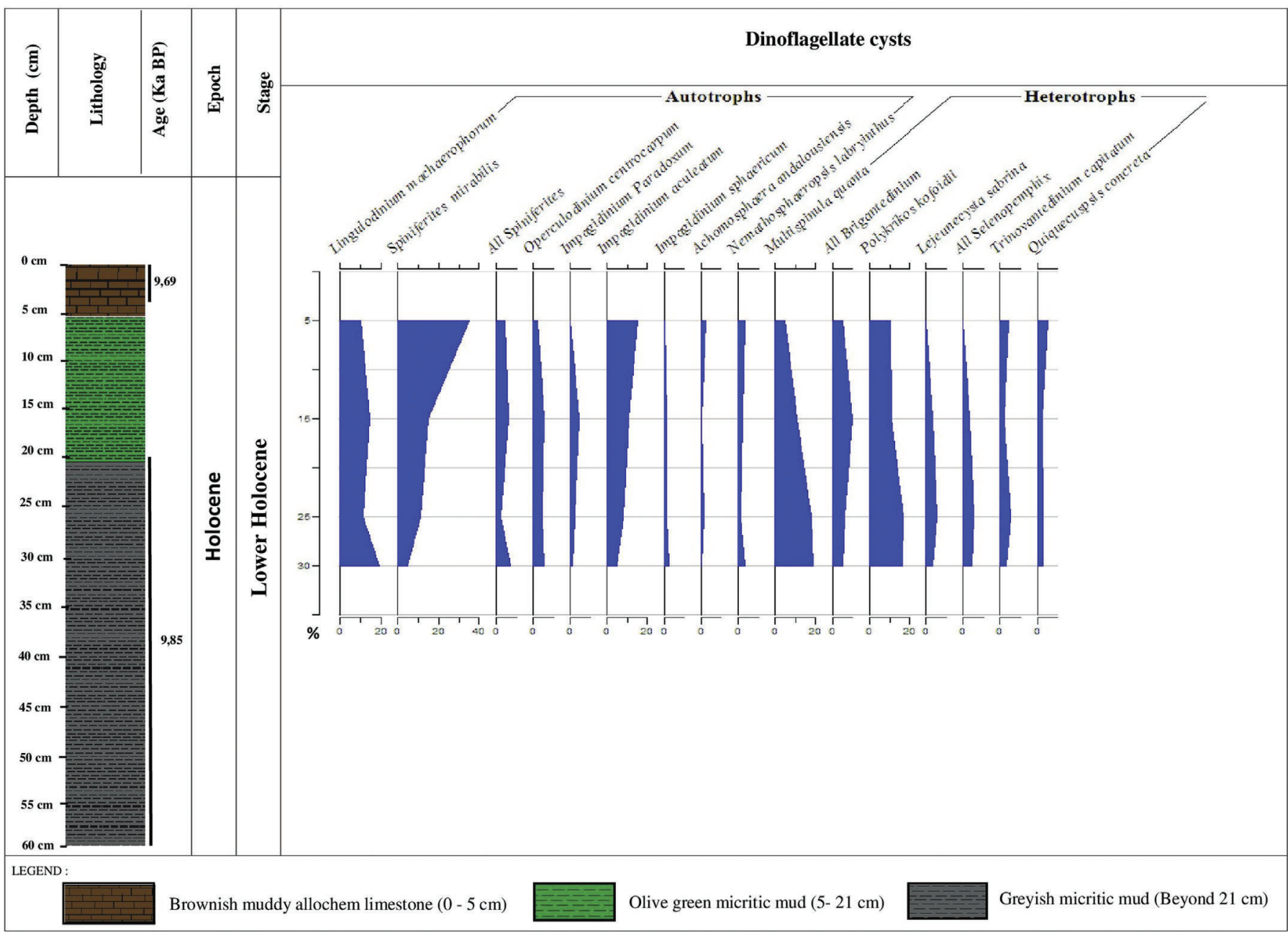

Fig. 4. Chart illustrating the total count and diversity of the marine and terrestrial palynomorphs, vertical stratigraphic distribution of the recorded dinoflagellate cysts per number of cysts counted in the boxcore MD 13-3465. Age: estimated sediment age (proposed by Stalder et al. (2015)), lithofacies: (Terhzaz, 2019).

decrease at the top. Operculodinium centrocarpum abundance values remain around $2-3 \%$. Spiniferites mirabilis increase in abundance from the bottom to the top of the sedimentary sequence from 5 to $20 \%$, while other species (S. bentorii, S. bulloideus, S. membranaceus, S. septentrionalis) have values from 5 and $8 \%$.

The oceanic species Impagidinium aculeatum display values between 8 and $17 \%$, and it is accompanied mainly by I. sphaericum (2-3\%). Heterotrophic cysts are diversified: Multispinula quanta present high percentages between 13 and 25\%, Lejeunacysta oliva and Lejeunacysta sabrina (1-3\%) appear from $25 \mathrm{~cm}$ to the surface, Selenopemphix quanta, S. sp. and S. nephroides (2-4\%) decrease in abundance towards the top of the sedimentary succession. Also present are: Polykrikos kofoidii and Polykrikos schwartzii (1-7\%) and Trinovantedinium capitatum (3-5\%). (Figs. 6, 7 and Plate I)

3.2.2.3. The box core MD13-3461:. MD13-3461 boxcore has a thickness of $80 \mathrm{~cm}$ and is composed of gray muddy micrite of the base to $15 \mathrm{~cm}$ and mud brownish micritic from 15 upward (Terhzaz et al., 2018).

The ages of the sediments are estimated at $6.29 \mathrm{ka}$, between 60 and $45 \mathrm{~cm}$, and $5.14 \mathrm{ka}$ between 5 and $0 \mathrm{~cm}$ (Terhzaz et al., 2018) and therefore, they belong to the middle Holocene (Northgrippian) (Walker et al., 2018). Five samples were taken from this box core from $80 \mathrm{~cm}$ up to the surface.
Dominated by autotrophic cysts, the assemblages are composed by the neritic species Spiniferites bentorii, S. bulloideus, S. membranaceus, S. hyperacanthus, S. delicatus and S. septentrionalis and by oceanic species such as Impagidinium patulum, I. paradoxum, I. sphaericum, Spiniferites mirabilis (external neritic species) and Impagidinium aculeatum are the dominant taxa; and their values fluctuate between 10 and $20 \%$. Operculodinium centrocarpum represents only the $3 \%$ of cyst assemblages. The contribution of Lingulodinium machaerophorum (internal neritic species) fluctuates around $10 \%$ but reaches $19 \%$ at the top of the sedimentary succession. Heterotrophic taxa are represented by Multispinula quanta (11-17\%). (Figs. 8 , 9 and Plate I)

3.2.2.4. The box core MD13-3468:. The box core MD13-3468 has a thickness of $40 \mathrm{~cm}$. Sediments consist of grayish micritic mud from 40 to $2 \mathrm{~cm}$ and a brownish micritic mud for the upper $2 \mathrm{~cm}$. Between 15 and $5 \mathrm{~cm}$, sediments are dated as old as $10.07 \mathrm{ka}$ (Schröder-Ritzrau et al., 2015) and thus, attributed to the upper Holocene/Meghalayian.

One sample was analyzed at the base of the core and two samples between $10 \mathrm{~cm}$ and the surface

The abundances of dinoflagellate cysts in these sediments is rather homogeneous, however, autotrophic cysts increase in abundance towards the top of the sedimentary succession. Lingulodinium machaerophorum has value fluctuating between 8 and $10 \%$. 
MD 13-34 65 - The Moroccan Mediterranean margin (Alboran Sea)

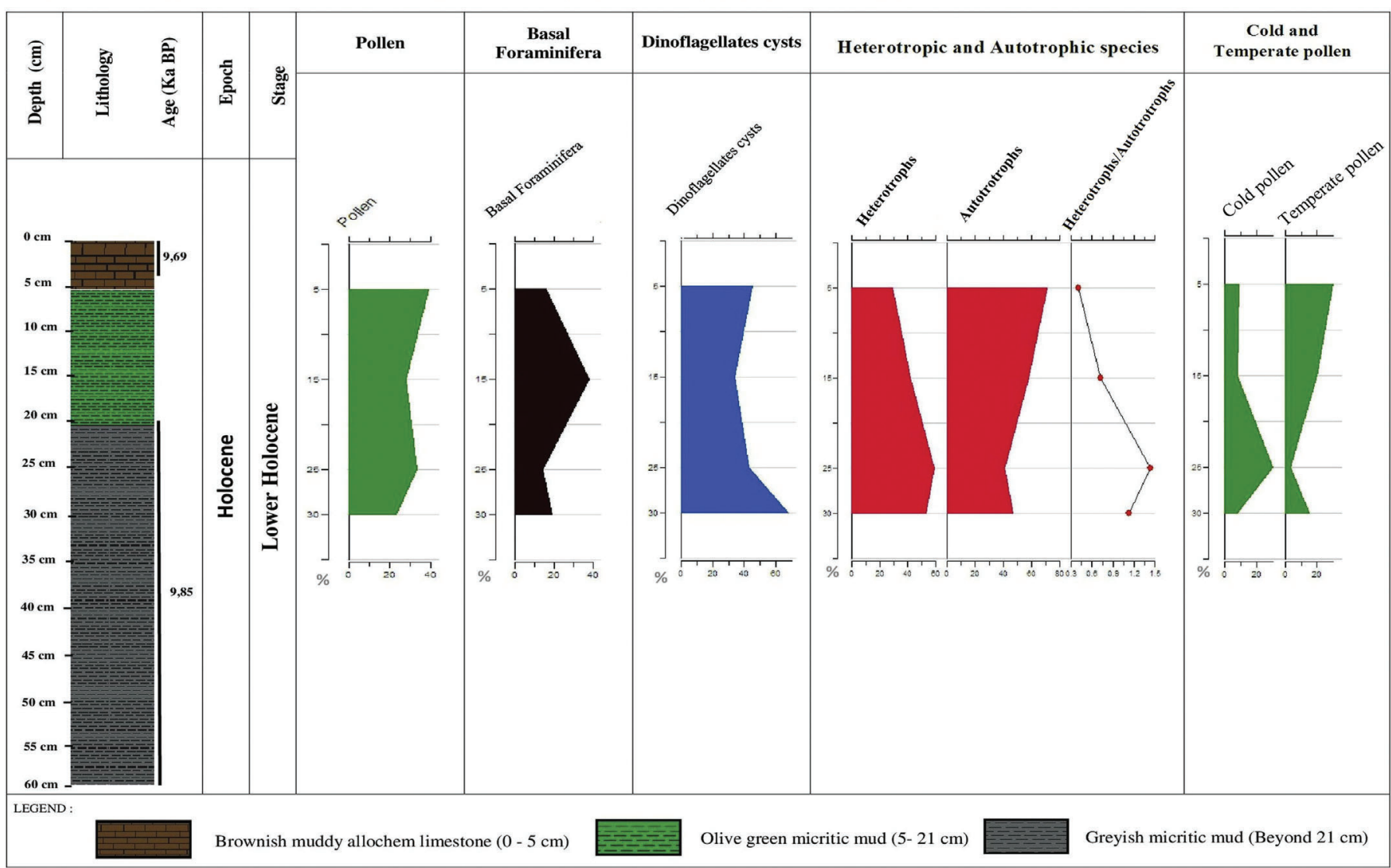

Fig. 5. Chart illustrating the total count and diversity of the marine and terrestrial palynomorphs, vertical stratigraphic distribution of the recorded pollen, basal foraminifera, Dinoflagellates cysts (total number) compared to all the palynological content, Heterotrophic and autotrophic species with the ratio (Heterotrophic/Autotrophic) per number of cysts counted and cold and temperate pollen per number of pollen counted in the boxcore MD 13-3465.

Operculodinium centrocarpum has low percentages, between 2 and 4\%. Spiniferites mirabilis, display abundances up to $35 \%$ while S. bentorii, $S$ bulloideus, S. membranaceus are rarer with values from 4 to $6 \%$ of the total. Spiniferites mirabilis is accompanied by Impagidinium aculeatum (11-15\%). Also present are Impagidinium paradoxum (3-7\%) and Impagidinium patulum (1\%). Heterotrophic taxa are represented by Multispinula quanta (7-13\%). (Figs. 10,11 and Plate I)

The microflora recorded in our sediments has very low rates: between 17 and 102 taxa, despite this low representativeness, it could be a valuable tool, in parallel with dinoflagellate cysts, for assessing climatic variations over the study interval. It is constituted by herbaceous and steppe species (Artemisia, Amaranthaceae-Chenopodiaceae, Asteraceae-Cichorioideae and Poaceae), Trees and shrubs (Deciduous Quercus, Evergeen Quercus, Ericaceae and Olea), and altitudinal conifers (Pinus, Cedrus, Abies and Picea).

The MD13-3441 box core (Upper Pleistocene/Tarantian-Middle Holocene.) shows three associations listed with a number of taxa between 17 and 68.

-The first corresponds to the Tarantian stage (12.09-11.7 ka), shows a dominance of trees and shrubs (67-79\%), coupled by altitudinal conifers (15-21\%), and the herbaceous and steppe species oscillates between 3 and $12 \%$.

-The second between 11.7 and $10.84 \mathrm{ka}$. This association displays herbaceous and steppe species (50-67\%); followed by trees and shrubs (14-23\%) and altitudinal conifers (19-28\%).
-The third occurs between 10.84 and $6.8 \mathrm{ka}$, shows a dominance of trees and shrubs with $59-64 \%$, followed by the altitudinal conifers (21-29\%)and finally herbaceous and steppe species (9-18\%).

The MD13-3468 and MD13-3465 cores reveals also three types of associations for the lower Holocene (10.07 and 9.69 Ka), contains 61 and 102 of taxa.

-The first, is visible around $10.07 \mathrm{ka}(\mathrm{MD} 13-3468)$, contains $61 \mathrm{pol}-$ len taxa with a dominance of herbaceous and steppe species of about $85 \%$, the trees and shrubs constitutes $12 \%$ and altitudinal conifers $3 \%$.

-The second association occurs at $9.85 \mathrm{ka}$ (MD13-3465) also dominated by herbaceous and steppe species (78\%), followed by trees and shrubs (14\%), and altitudinal conifers at $8 \%$.

-The third at 9.69 ka (MD13-3465), is slightly different from the first two associations: herbaceous and steppe species (83\%), outrun the trees and shrubs $9 \%$, followed by altitudinal conifers ( $8 \%$ ).

From 6.29 to 5.14 ka: two cores: core MD13-3461 (6.29-5.14 ka) and core MD13-3456 (5.9-5.45 ka) are representative of the middle Holocene stage.

-The pollen content of the sediments of both cores displays a number of taxa between 35 and 75: 75 taxa in the core MD13-3456 (5.9 ka), 42 in MD13-3456 (5.45 ka), 48 in MD13-3461(5.14 ka) and 35 in MD13-3461 (6.25 ka). 
MD 13-34 56 - The Moroccan Mediterranean margin (Alboran Sea)

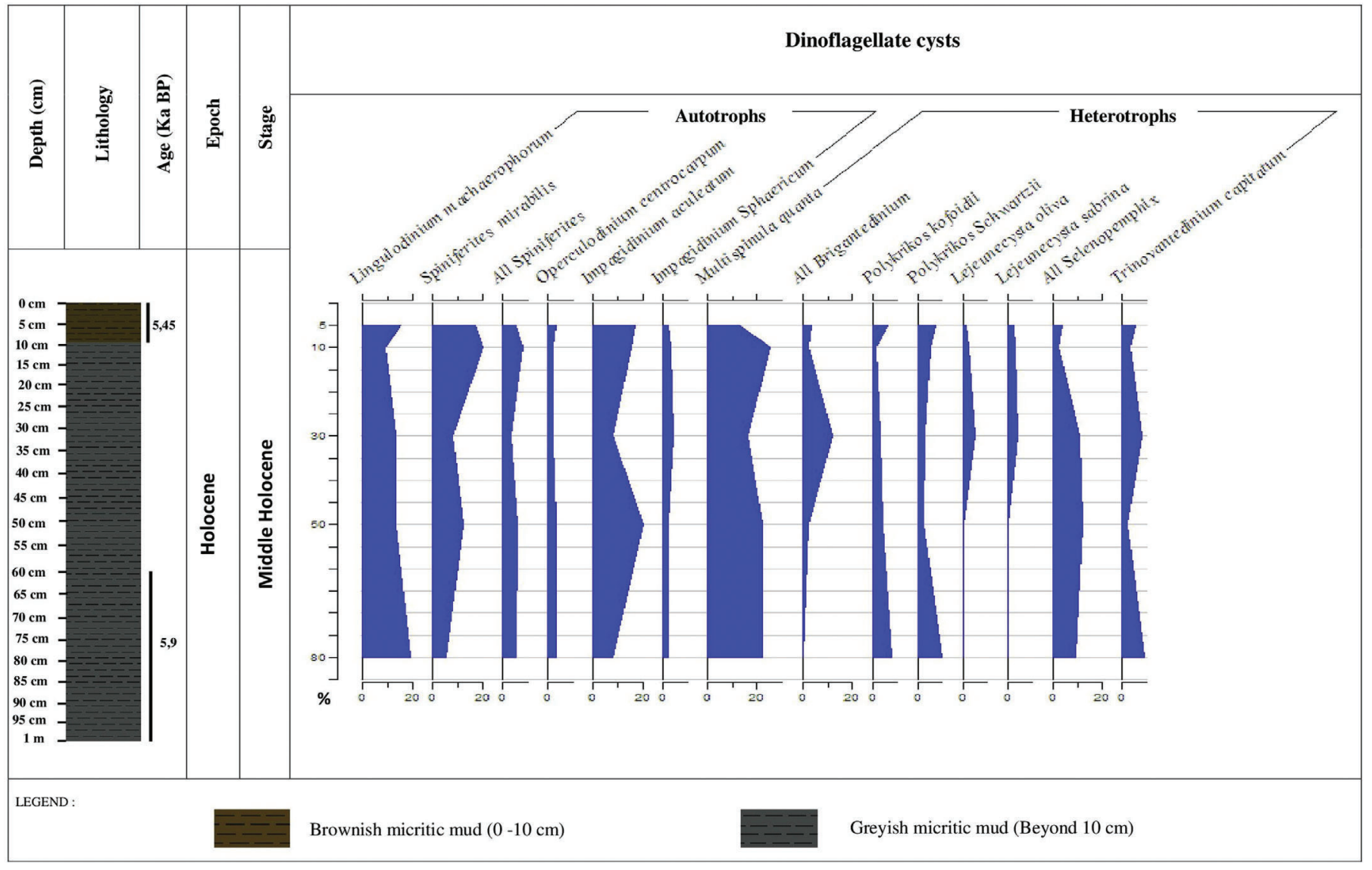

Fig. 6. Chart illustrating the total count and diversity of the marine palynomorphs, vertical stratigraphic distribution of the recorded dinoflagellate cysts per number of cysts counted in the boxcore MD 13-3456. Age: estimated sediment age (proposed by Stalder et al. (2015)), lithofacies: (Terhzaz, 2019).

-It shows a dominance of herbaceous and steppe species between 5.9 and $5.14 \mathrm{ka}$ with percentages oscillating between 39 and $67 \%$ (MD13-3456) and 75\% (MD13-3461). Whereas 35 pollen taxa are dominated by trees and shrubs 57\% in MD13-3461 box core (6.29 ka), followed by altitudinal conifers (23\%) and then herbaceous and steppe elements with a percentage of $20 \%$.

\subsection{Interpretation and discussion}

Palynological analysis of organic residues obtained after treatment with strong acids ( $\mathrm{HCl}$ and $\mathrm{HF}$ ) reveals a good richness of the marine fraction (54-90\%) compared to pollen grains (10 and 46\%), with a clear dominance of dinoflagellate cysts (29-85\%) (Figs. 3, 5, 7, 9 and 11). Despite the low representativeness of pollen grains, they may be a valuable tool, in parallel with dinoflagellate cysts, for assessing climatic variations over the study interval: Late Pleistocene-Middle Holocene.

For dinoflagellate cysts, two groups are distinguished by two opposite polarity regarding the temperature (Harland, 1983; MorzadecKerfourn, 1984, 1988; Penaud et al., 2009; Rouis-Zargouni, 2010).

- The group of temperate-warm cysts (WT) includes species belonging to the genus Impagidinium (Stover and Evitt, 1978); the species of this genus have a maximal abundance between $40^{\circ}$ and $30^{\circ}$ north parallel (Harland, 1983; Zonneveld et al., 2013). The most temperate forms are Impagidium patulum, Impagidium paradoxum and Impagidium aculeatum. Most species of genus Impagidinium are presently dominant in warm tropical and warm temperate waters between $20^{\circ} \mathrm{N}$ and $35^{\circ} \mathrm{N}$, covering a wide range of temperatures (Edwards and Andrle, 1992; Rochon et al., 1999; Marret and Zonneveld, 2003b) and are indicative of an oceanic setting (Harland, 1983; Turon, 1984; Bouimetarhan et al., 2009a). They are accompanied by species belonging to the genus Spiniferites (Mantell et al., 1850): Spiniferites mirabilis, Spiniferites delicatus and Spiniferites membranaceus, which are typical of neritic to oceanic environments (Wall et al., 1977).

- The group of cold-temperate cysts (CT) includes Operculodinium centrocarpum species, a neritic form dominating the continental slope (Morzadec-Kerfourn, 1988). The distribution of this cyst in the surface sediments appears to be associated with the North Atlantic Current (Harland, 1983; Zonneveld et al., 2003; Rouis-Zargouni, 2010). The distribution of this species is observed from polar, equatorial and coastal regions to the open ocean (Rochon, 1997; Zonneveld et al., 2013). It may be abundant in sites where water temperature is higher than $0{ }^{\circ} \mathrm{C}$ throughout the year. High relative abundances can be observed in polar areas where salinities are reduced as a result of the melt water input during the summer season or due to the fresh water discharge from rivers. It tolerates a variety of temperature and salinity conditions. However, it is a good indicator of the penetration of North Atlantic warm waters into the Bay of Biscay (Penaud et al., 2008).The Nemathosphearopsis labyrinthus species is a typical oceanic species. Its maximum distribution in the North Atlantic is between $45^{\circ}$ and $65^{\circ}$ North (Rochon et al., 1999; Marret et al., 2004; de Vernal et al., 2005; Zonneveld et al., 2003). Nematosphaeropsis labyrinthus (Ostenfeld, 1903; Reid, 1974; Zonneveld et al., 2003) is a cosmopolitan species which may be relatively highly abundant in eutrophic as well as oligotrophic environments. A wide tolerance for sea surface temperatures 
MD 13-34 56 - The Moroccan Mediterranean margin (Alboran Sea)

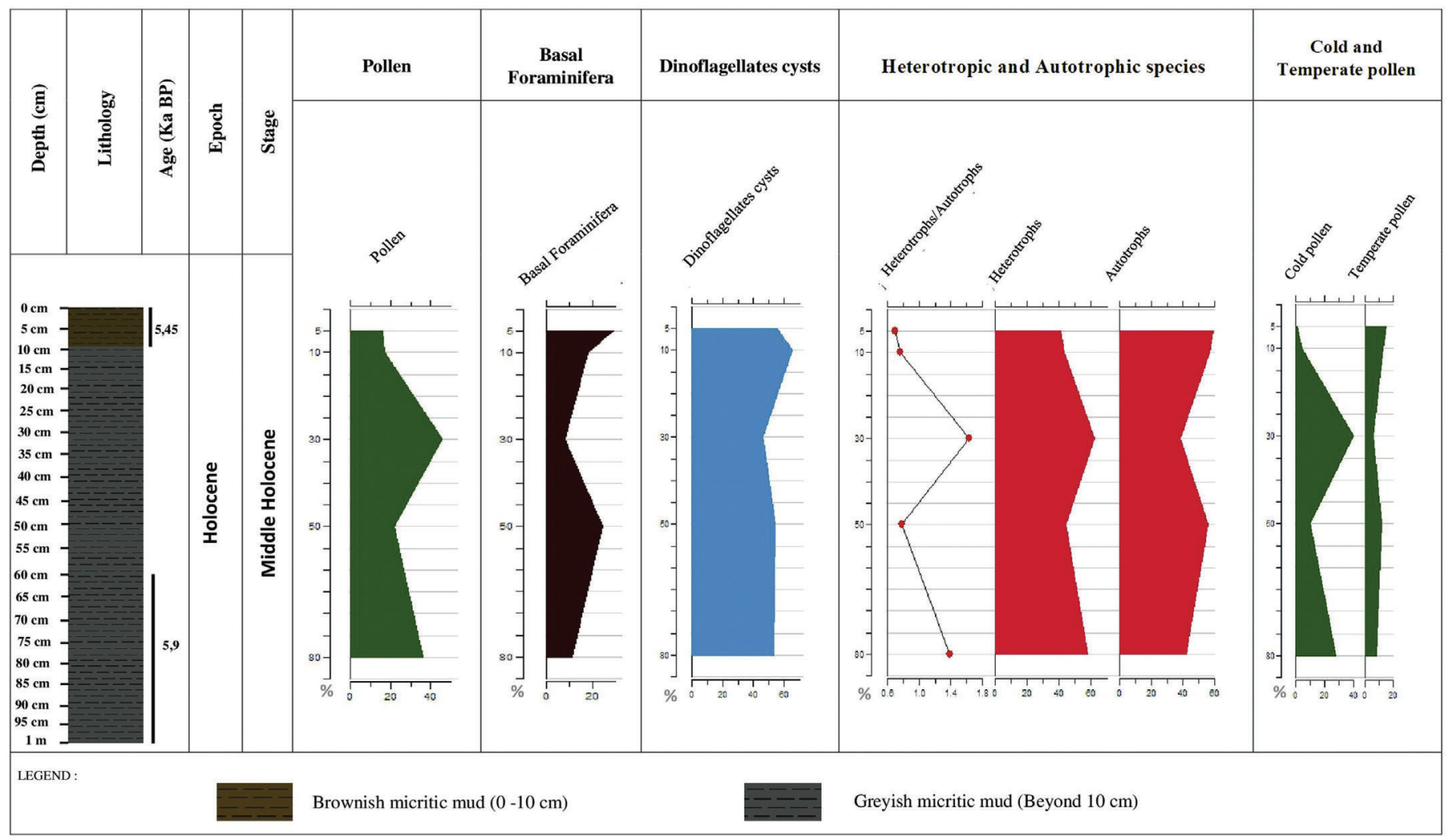

Fig. 7. Chart illustrating the total count and diversity of the marine and terrestrial palynomorphs, vertical stratigraphic distribution of the recorded pollen, basal foraminifera, Dinoflagellates cysts (total number) compared to all the palynological content, heterotrophic and autotrophic species with the ratio (Heterotrophic/Autotrophic) per number of cysts counted and cold and temperate pollen per number of pollen counted in the boxcore MD 13-3456.

ranging from 2.1 to $29.8^{\circ} \mathrm{C}$ (Spring-Summer) and 25.8 to $39.4{ }^{\circ} \mathrm{C}$ (Summer-Autumn) exist excepted for two sites in the North Atlantic Ocean and the Beaufort Sea where sea surface temperatures vary between 17.4 and $20.2^{\circ} \mathrm{C}$, respectively (Zonneveld et al., 2013b)

Although present in areas where bottom water are anoxic/hypoxic, high relative abundances can be also observed in areas where the seafloor is well ventilated. Nematosphaeropsis labyrinthus characterizes oceanic upwelling areas where it dominates the assemblages (Ostenfeld, 1903; Reid, 1974; Zonneveld et al., 2003).

The species Spiniferites lazus is typical of subpolar to temperate regions in the North Atlantic. It can be observed in the open sea, coastal sites with high concentrations of nitrates and well-ventilated bottom water (Reid, 1974; Zonneveld et al., 2003).

Heterotrophic dinoflagellate tolerate wider variations in salinity and temperature and are more dependent on nutrients (Marret and Zonneveld, 2003a). Moreover, they dominate in upwelling regions permanent or seasonal (Taylor and Pollingher, 1987; Marret, 1994; Zonneveld et al., 2001; Radi and Vernal, 2004). They become abundant in presence of high prey availability (diatoms, flagellates, bacteria) (Hansen, 1991; Landry et al., 2000; Grattepanche et al., 2011). Their dominance is also reported in high latitude environments (Rochon et al., 1999). Therefore, heterotrophic dinoflagellate are increasingly considered as indirect markers of primary productivity (Wall et al., 1977; Marret, 1994; Dale, 1996; Zonneveld, 1997; Zonneveld et al., 2001; Dale et al., 2002; Sangiorgi et al., 2002; Marret and Zonneveld, 2003b; Sprangers et al., 2004; Susek et al., 2005; Holzwarth et al., 2007; Pospelova et al., 2008).

The sediments from box core MD13-3441 contain abundant late Pleistocene/Tarentien cold taxa. The species Spiniferites lazus, Nematosphaeropsis labyrinthus, Impagidinium sphaericum indicate an outer neritic to an oceanic environment rich in nutrients (Turon and Londeix, 1988; Devillers and de Vernal, 2000). These species have a dominant latitudinal distribution beyond North 50th parallel.

These cold taxa significantly decreasing upward from the Holocene/ Greenlandian. They are replaced by Spiniferites mirabilis and Impagidinium aculeatum in the sediments from the middle Holocene/ Northgrippian. The abundance of Lingulodinium machaerophorum in this box core indicates that the sediments were deposited in an environment rich in nutrients from the continent possibly upwelled from the sea floor (Bouimetarhan et al., 2009; Zonneveld et al., 2013)

In this sedimentary succession, a temporary increase in heterotrophic cysts indicative of upwelling (Taylor and Pollingher, 1987) suggest that during the lower Holocene upwellings condition characterized the region.

Middle Holocene sediments recovered on the Moroccan Mediterranean margin (box core MD13-3461) observe:

- A notable increase in the percentages of Impagidinium aculeatum comparable to that of Spiniferites mirabilis suggesting temperate waters.

- Heterotrophic taxa show good development at the base of the core and regress to the top.

The sediments recovered in box core MD13-3456 are middle Holocene in age. As in MD13-3461 box core:

- Thermophilic taxons Impagidinium aculeatum and Spiniferites mirabilis are the most dominant.

- Lingulodinium machaerophrum is still present with the abundance of heterotrophic species, which testifies to the contribution of the continent in nutrients.

The sediments recovered in box core MD13-3465 are dated as old as the lower Holocene, between 9.69 and $9.85 \mathrm{ka}$. The absence of Spiniferites lazus (CT) and the decrease in abundance of the cold taxa 


\section{13-34 61 - The Moroccan Mediterranean margin (Alboran Sea)}

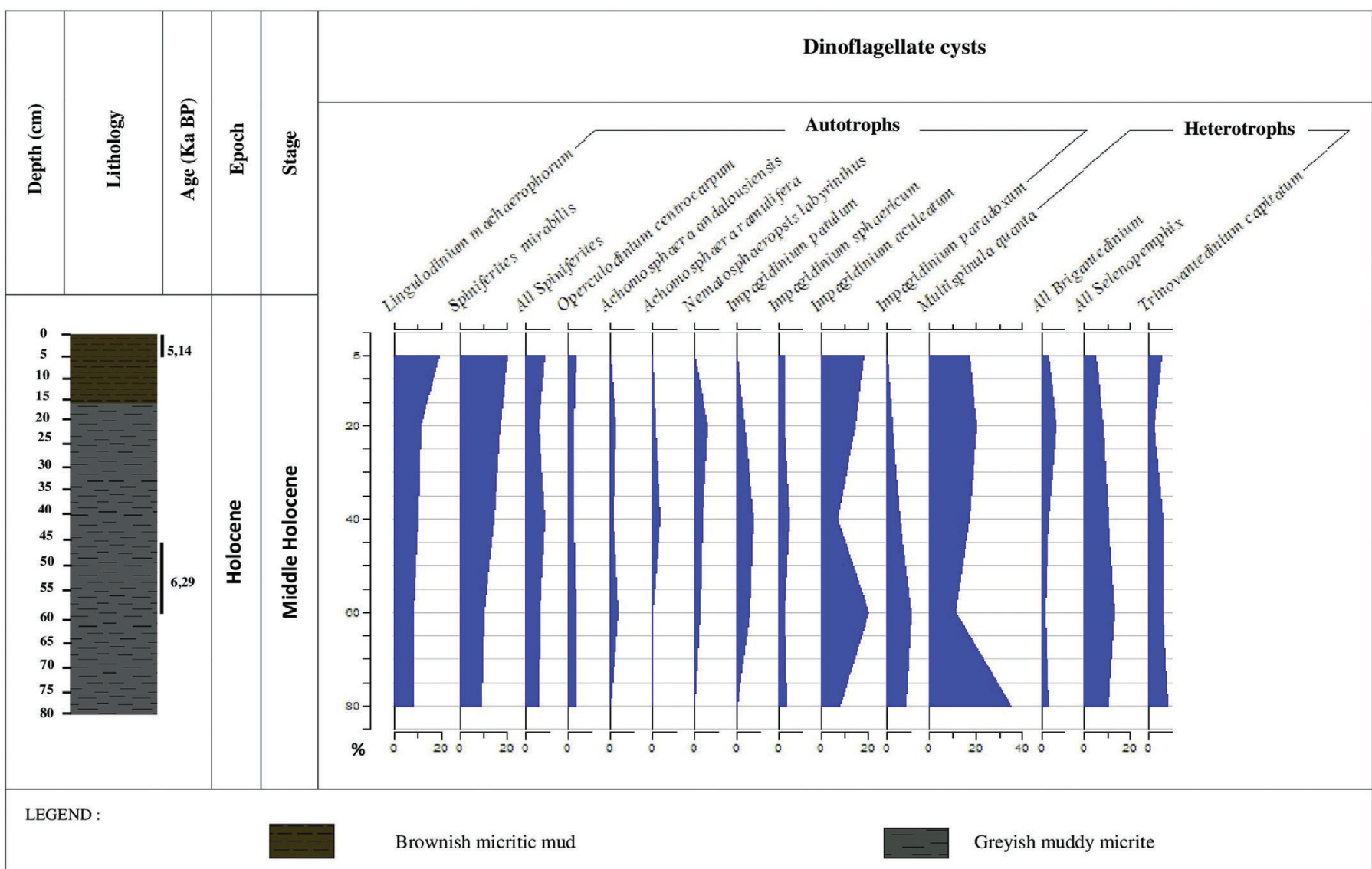

Fig. 8. Chart illustrating the total count and diversity of the marine and terrestrial palynomorphs, vertical stratigraphic distribution of the recorded dinoflagellate cysts per number of cysts counted;in the boxcore MD 13-3461. Age: estimated sediment age (proposed by Stalder et al. (2015)), lithofacies: (Terhzaz, 2019).

Nematosphaeropsis labyrinthus accompanied by the increase in abundance of Spiniferites mirabilis and Impagidinium aculeatum (WT) indicate the initial establishment of temperate water conditions. The influence of neritic input, detected by the presence of Lingulodinium machaerophorum, is relatively modest.

The progressive warming is suggested also by the increasing abundances of the autotrophs taxa Spiniferites mirabilis and Impagidinium aculeatum in the Lower Holocene sediments recovered in box core MD13-3468.

The sediments recovered in the southern part of the Alboran Sea also record the installation of the temperate conditions from the lower Holocene to middle Holocene, during the Holocene climatic optimum. In this time interval, inner neritic to oceanic dinoflagellate assemblages includes the taxa Spiniferites mirabilis and Impagidinium aculeatum (WT) in equal percentages (Zapata et al., 2013) documented that the lower Holocene in the area of Ifri Oudadane in NE Morocco was characterized by the cyclicity of hot and humid phases. The interval from 11 to $7.6 \mathrm{ka}$ was characterized by a hot-humid climate; the interval from 7.6 to 6.6 ka was characterized by a humid-warm climate, with maximum humidity between 7.4 and 6, 6 ka. This was confirmed by the investigation performed on the sediments from box core MD13-3441, MD13-3465 and MD13-3468 in the Atlantic and Mediterranean. In particular, during the Younger Dryas a well known cold period in the Holocene (Barbaza, 2011), the cold water taxon Nematosphaeropsis labyrinthus dominated. Immediately after this cold time, in the middle Holocene, this taxon is replaced by thermophilic taxa such as Impagidinium aculeatum and Spiniferites mirabilis, which suggesting warming.
During the lower Holocene (9.69-9.85 ka) the sedimentary archive recovered in MD 13-3465 box core reveals the existence of semi-arid climatic conditions. This semi-arid climate phase was followed by an arid climate at 10.07 ka box core MD 13-3468 (Terhzaz et al., 2018). The microflora, despite its low representativeness, corroborated these results by the predominance of herbaceous and steppe elements (Asteraceae-Cichorioideae, Amaranthaceae-Chenopodiaceae, Artemisia and Poacea) suggests that the continental climate varied between semi-arid (9.85 ka) and arid (9.69 ka), thus indicating a warm temperate marine environment and climate oscillating between semi-arid to arid around $10.07 \mathrm{ka}$ (MD 13-3468). These results are consistent with those obtained by Terhzaz et al. (2018).

During the middle Holocene (6.29 ka), the palynological data (MD 13-3461) suggest the establishment of a semi-humid climate confirmed by the dominance of tree and shrubs pollen (Deciduous Quercus, Evergeen Quercus, Ericaceae and Olea). This semi-humid climate was followed by a dry warm phase, from 5.45 to 5.14 ka (MD 13-3456 and MD 13-3461) as suggested by the decrease in abundance of cold climate species (trees and shrubs) and by the abundance of herbaceous pollens and steppe species (Asteraceae-Cichorioideae, AmaranthaceaeChenopodiaceae, Artemisia and Poacea).

The heterotrophic vs. autotrophs can be successfully used to test the climate hypothesis expressed in this research (Fig. 11). This ratio can be used as a proxy for paleotemperature: lower ratio corresponds to warmer waters (Pospelova et al., 2006).

Fletcher (2013) reconstructed the middle Holocene climate for the western Mediterranean and suggested that a dry climate prevailed at 
MD 13-34 61 - The Moroccan Mediterranean margin (Alboran Sea)

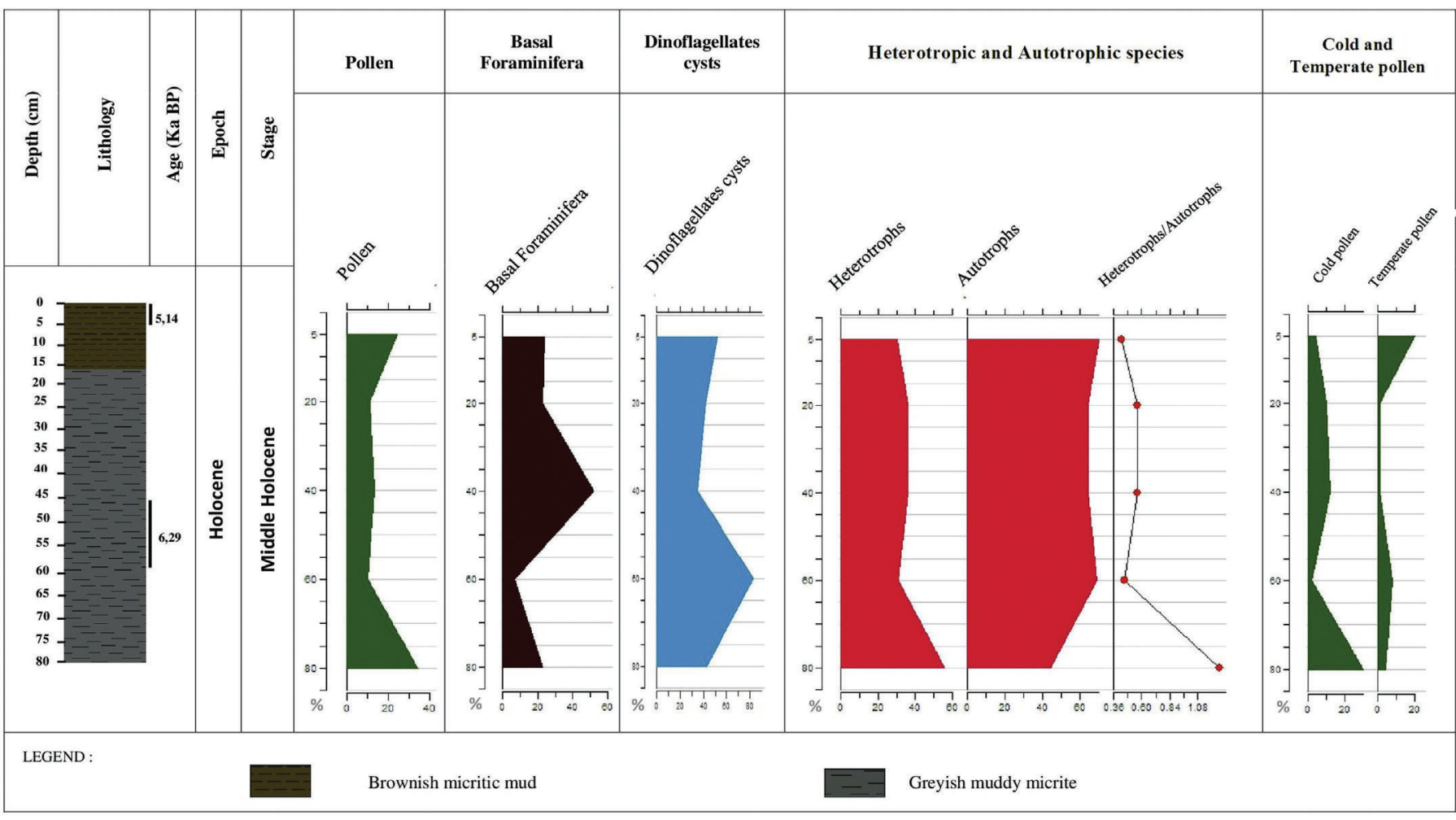

Fig. 9. Chart illustrating the total count and diversity of the marine and terrestrial palynomorphs, vertical stratigraphic distribution of the recorded pollen, basal foraminifera, - Dinoflagellates cysts (total number) compared to all the palynological content, Heterotrophic and autotrophic species with the ratio (Heterotrophic/Autotrophic) per number of cysts counted and cold and temperate pollen per number of pollen counted in the boxcore MD13-3461.

MD 13-34 68 - The Moroccan Mediterranean margin (Alboran Sea)

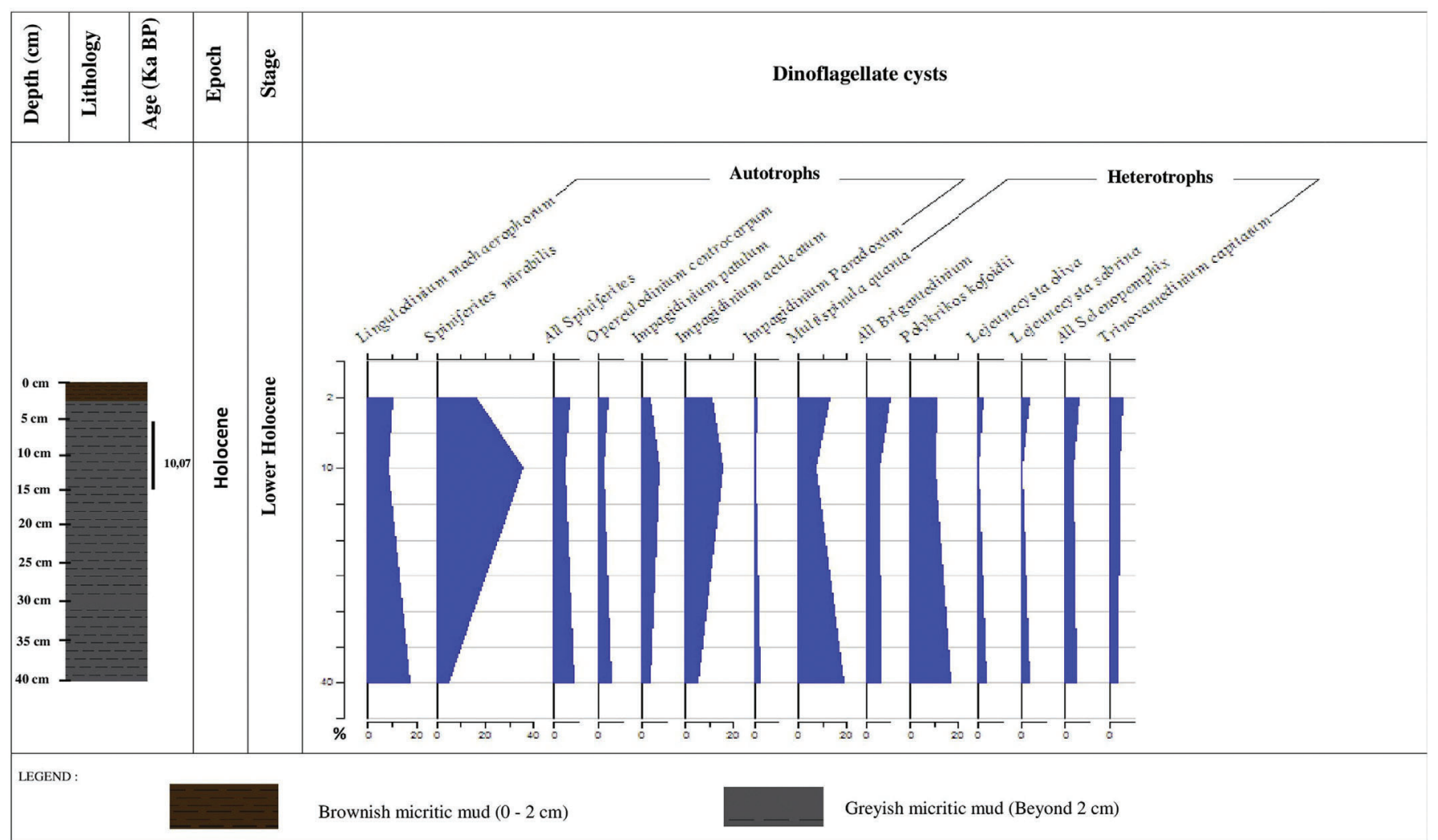


MD 13-34 68 - The Moroccan Mediterranean margin (Alboran Sea)

\begin{tabular}{|c|c|c|c|c|c|c|c|c|c|}
\hline 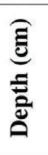 & 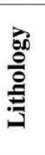 & 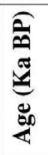 & 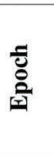 & $\begin{array}{l}\text { 总 } \\
\text { 峞 }\end{array}$ & Pollen & $\begin{array}{c}\text { Basal } \\
\text { Foraminifera }\end{array}$ & Dinoflagellates cysts & Heterotropic and Autotrophic species & $\begin{array}{c}\text { Cold and Temperate } \\
\text { pollen }\end{array}$ \\
\hline $\begin{array}{l}0 \mathrm{~cm} \\
5 \mathrm{~cm} \\
10 \mathrm{~cm} \\
15 \mathrm{~cm} \\
20 \mathrm{~cm}\end{array}$ & & 10,07 & 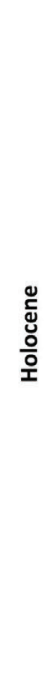 & 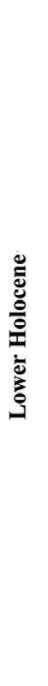 & (1) & $f_{\%}^{-1}$ & - & -100 & $\underbrace{0}_{-1}$ \\
\hline LEGEL & & & & & & $\mathrm{d}(0-2 \mathrm{~cm})$ & & Sreyish micritic mud (Beyond $2 \mathrm{~cm}$ ) & \\
\hline
\end{tabular}

Fig. 11. Chart illustrating the total count and diversity of the marine and terrestrial palynomorphs, vertical stratigraphic distribution of the recorded pollen, basal foraminifera, - Dinoflagellates cysts (total number) compared to all the palynological content. Heterotrophic and autotrophic species with the ratio (Heterotrophic/Autotrophic) per number of cysts counted and cold and temperate pollen per number of pollen counted in the boxcore MD 13-3468.

Table 2

Species list used in the Atlantic and Mediterranean Moroccan margins.

\begin{tabular}{ll}
\hline Autotrophic species & \multicolumn{1}{c}{ Heterotrophic species } \\
\hline Achomosphaera andalousiensis & Brigantedinium spp \\
Achomosphaera ramulifera & Brigantedinium cariacoense \\
Lingulodinium machaerophorum & Brigantedinium irregulare \\
Operculodinium centrocarpum & Brigantedinium simplex \\
Impagidinium aculeatum & Brigantedinium asymmetricum \\
Impagidinium paradoxum & Lejeunecysta oliva \\
Impagidinium patulum & Lejeunecysta sabrina \\
Impagidinium sphaericum & Multispinula quanta \\
Nematosphaeropsis labyrinthus & Polykrikos kofoidii \\
Spiniferites bentorii & Polykrikos schwartzii \\
Spiniferites bulloideus & Quinquecuspis concreta \\
Spiniferites membranaceus & Selenopemphix nephroides \\
Spiniferites hyperacanthus & Selenopemphix quanta \\
Spiniferites mirabilis & Trinovantedinium capitatum \\
Spiniferites septentrionalis & \\
Spiniferites lazus & \\
\hline
\end{tabular}

around $5.45 \mathrm{ka}$. The interpretation of the heterotrophic vs. autotrophs ratio (Fig. 11, Table 2) seems to confirm the assumption of Fletcher (2013) but disagrees with Terhzaz et al. (2018) who suggested semiarid-subhumid climate during the interval from 6.29 to $5.14 \mathrm{ka}$. However, unstable environmental conditions during this time, as suggested by evidence of stress in the ostracod species Krithe praetexta (Pirkenseer, 2018) may account for the discrepancy.

\section{Conclusion}

This work is the first study on palynology of carbonate mound sediments in the Moroccan Atlantic and Mediterranean margins. The organic remaining revealed the presence of associations rich in palynomorphs (pollen, dinoflagellate cysts, and basal chitinous foraminifera). Variations in the relative frequencies of the selected taxa (which have a recognized environmental value) allowed the reconstruction of the paleoenvironments during the interval: Terminal PleistoceneMiddle Holocene.

Despite the low representativeness of the continental fraction (spores and pollen) in our organic residues, its contribution remains a valuable tool for the interpretation of climate change.

The dinoflagellate cysts assemblages identified in Pleistocene/ Tarantian sediments (11.7-12.09 ka), recovered along the Moroccan Atlantic margin (box core MD13-3441), contain abundant cold-water taxa, mainly Nemathosphearopsis labyrinthus. This signal has been observed in sediments from all the sites in the phase coinciding with the Young Dryas. Heterotrophic taxa also suggest increased marine productivity during this time. The cold assemblage consisting of Spiniferites lazus and Impagidinium sphaericum indicate that the sediments were deposited in the external neritic to oceanic areas, in a nutrient-rich environment. The significant presence of pollen from trees and shrubs (Deciduous Quercus, Evergeen Quercus and Ericaceae and Olea) coupled by altitudinal conifers (Pinus, Cedrus, Abies and Picea) confirms that the cold climate prevailed in both the continental and marine environments.

The early Holocene (11-7.6 ka) was characterized by the passage from outer neritic to the inner neritic environment and decrease abundances of cold taxa. The remarkable appearance of thermophilic taxa such as Spiniferites mirabilis and Impagidinium acculeatum and the establishment of cyclical hot and humid phases. Pollens indicate a climatic oscillation from arid to humid during this period, whose arid period (11.7-10.84 ka) was characterized by dominance of herbaceous and steppe elements, and the humid period (10.84-6.8 ka) is characterized by dominance of trees and shrubs. 

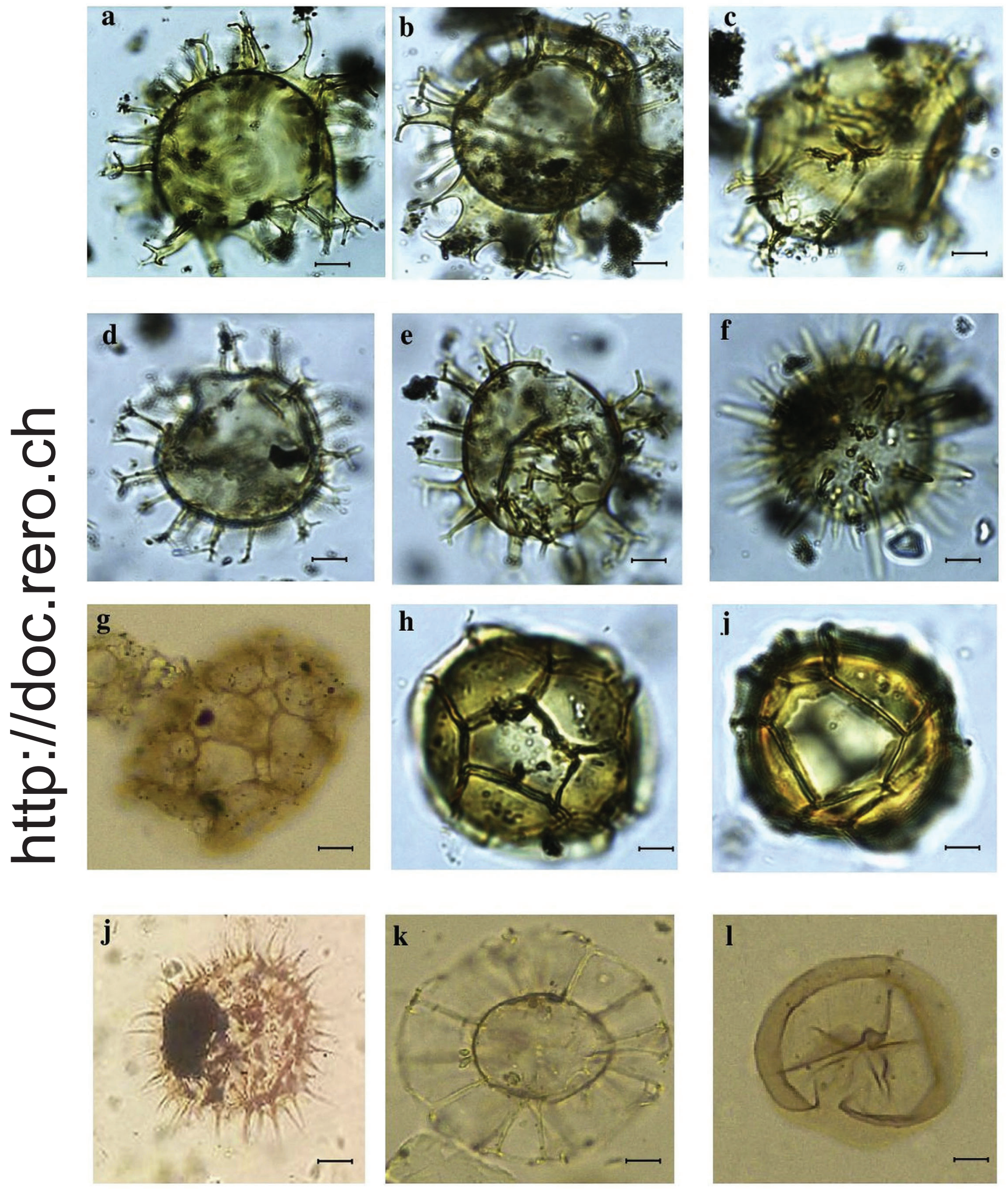

Plate I. Some common specimens from all the boxes cores. Scale bar $=40$ um. (a) Spiniferites membranaceus; (b) Spiniferites mirabilis; (c) Spiniferites bentorii; (d) Spiniferites bulloideus; (e) Spiniferites septentrionalis; (f) Lingulodinium machaerophorum; (g) Polykrikos kofoidii; (h) Impagidinium,patulum; (i) Impagidinium sphaericum; (j) Selenopemphix quanta; (k) Nematosphaeropsis labybrinthus; (1) Selenopemphix nephroides. 
During the middle Holocene (6.29-5.14 ka) the thermophilic Spiniferites mirabilis and Impagidinium acculeatum dominated the dinoflagellate cysts assemblages. Their presence coupled with the autotrophic vs heterotrophic ratio suggests warmer waters in the marine environment. This, in turn, may reflect an inner neritic to ocean environment with continental climate fluctuating between semi-humid and dry warm climate:

This interval includes: The base (6.29 ka) whose microflora dominated by trees and shrubs (Deciduous Quercus, Evergeen Quercus, Ericaceae and Olea) reflecting a semi-humid climate.

However, the interval between 5.9 and 5.14 ka marking a dry warm climate by the dominance of herbaceous and steppe elements (Asteraceae-Cichorioideae, Amaranthaceae-Chenopodiaceae, Artemisia and Poacea).

Continental climate change seems to have no significant impact on the growth and demise of the deep cold-water coral ecosystems, however, the hydrodynamic conditions, nutrient supply and tectonic have a direct impact on these features in the Gulf of Cadiz and Alboran Sea (Terhzaz et al., 2018)

\section{Declaration of Competing Interests}

The authors declare that they have no known competing financial interests or personal relationships that could have appeared to influence the work reported in this paper.

\section{Acknowledgement}

This study was carried out in the frame of the ESF COCARDE European Research Network and the Research Foundation Flanders (FWO) ICA COCARDE project.

The MD194 EUROFLEETS cruise was carried out under Grant Agreement n. 228344, with full and duly acknowledged support of IPEV.

The Swiss National Foundation Projects 200020_131829 partially funded the MD194 EUROFLEETS cruise for the recovery of the boxcores.

\section{References}

Aguilar, R., Pastor, X., Garcia, S., et al., 2013. Importance of seamounts-like features for Mediterranean marine habitats and threatened species. Rapports de la Commission international pour la Mer Méditerranée 40, 716.

Ambar, I., Serra, N., Neves, F., Ferreira, T., 2008. Observations of the Mediterranean undercurrent and eddies in the Gulf of Cadiz during 2001. J. Mar. Syst. 71, 195-220. https:// doi.org/10.1016/j.jmarsys.2007.07.003.

Barathon, J.J., 1987a. Les vents et leurs régimes dans les bassins du Rif oriental: l'exemple de la station météorologique de Nador-Taouima. Le climat, la montagne, l'homme 17-23.

Barathon, J.-J., 1987b. Bassins et littoraux du Rif oriental (Maroc): évolution morphoclimatique et tectonique depuis le néogène supérieur. PhD Thesis. Poitiers.

Barbaza, M., 2011. Environmental changes and cultural dynamics along the northern slope of the Pyrenees during the Younger Dryas. Quat. Int. 242, 313-327. https:// doi.org/10.1016/j.quaint.2011.03.012.

Benzohra, M., Millot, C., 1995. Characteristics and circulation of the surface and intermediate water masses off Algeria. Deep-Sea Res. I Oceanogr. Res. Pap. 42, 1803-1830. https://doi.org/10.1016/0967-0637(95)00043-6.

Biberson, P., 1971. Essai de redéfinition des cycles climatiques du Quaternaire continental du Maroc. Quaternaire 8, 3-13.

Bouimetarhan, I., Dupont, L., Schefuß, E., et al., 2009a. Palynological evidence for climatic and oceanic variability off NW Africa during the late Holocene. Quat. Res. 72 188-197. https://doi.org/10.1016/j.yqres.2009.05.003.

Bouimetarhan, I., Marret, F., Dupont, L., Zonneveld, K., 2009b. Dinoflagellate cyst distribution in marine surface sediments off West Africa $\left(17-6^{\circ} \mathrm{N}\right)$ in relation to sea-surface conditions, freshwater input and seasonal coastal upwelling. Mar. Micropaleontol. 71,113-130. https://doi.org/10.1016/j.marmicro.2009.02.001.

Bouslam, M., 1989. Recherches sur les ambiances climatiques dans une région méditerranéenne: la Basse-Moulouya (Maroc) PhD Thesis, Toulouse 2.

Carter, T.G., Flanagan, J.P., Jones, C.R., et al., 1972. A New Bathymetric Chart and Physiography of the Mediterranean Sea. A Natural Sedimentation Laboratory, The Mediterranean Sea, pp. 1-23.

Comas, M., Pinheiro, L.M., 2007. Discovery of Carbonate Mounds in the Alboran Sea: The Melilla Mound Field. p. 1.
Comas, M., Platt, J.P., Soto, J., Watts, A., 1999. The origin and tectonic history of the Alboran Basin: Insights from leg 161 results. Integrated Ocean Drilling Program: Preliminary Reports, pp. 555-580.

Dale, B., 1976. Cyst formation, sedimentation, and preservation: Factors affecting dinoflagellate assemblages in recent sediments from trondheimsfjord, Norway. Rev. Palaeobot. Palynol. 22, 39-60. https://doi.org/10.1016/0034-6667(76)90010-5.

Dale, B., 1996. Dinoflagellate cyst ecology: Modeling and geological applications. Palynology: Principles and Applications 3, 1249-1275.

Dale, B., Dale, A.L., Jansen, J.H.F., 2002. Dinoflagellate cysts as environmental indicators in surface sediments from the Congo deep-sea fan and adjacent regions. Palaeogeography, Palaeoclimatology, Palaeoecology 185, 309-338 https://doi.org/ 10.1016/S0031-0182(02)00380-2.

De Mol, L., Van Rooij, D., Pirlet, H., et al., 2011. Cold-water coral habitats in the Penmarc'h and Guilvinec Canyons (Bay of Biscay): Deep-water versus shallow-water settings. Mar. Geol. 282, 40-52. https://doi.org/10.1016/j.margeo.2010.04.011.

De Mol, L., Hilário, A., Van Rooij, D., Henriet, J.-P., 2012. Habitat mapping of a cold-water Coral Mound on Pen Duick Escarpment (Gulf of Cadiz). Seafloor Geomorphology as Benthic Habitat. Elsevier, pp. 645-654.

de Vernal, A., Eynaud, F., Henry, M., et al., 2005. Reconstruction of sea-surface conditions at middle to high latitudes of the Northern Hemisphere during the Last Glacial Maximum (LGM) based on dinoflagellate cyst assemblages. Quat. Sci. Rev. 24, 897-924. https://doi.org/10.1016/j.quascirev.2004.06.014.

Devillers, R., de Vernal, A., 2000. Distribution of dinoflagellate cysts in surface sediments of the northern North Atlantic in relation to nutrient content and productivity in surface waters. Mar. Geol. 166, 103-124. https://doi.org/10.1016/S0025-3227(00) 00007-4.

Edwards, L.E., Andrle, V.A.S., 1992. Distribution of selected dinoflagellate cysts in modern marine sediments. Neogene and Quaternary Dinoflagellate Cysts and Acritarchs, pp. 259-288.

Eynaud, F., Turon, J.L., Duprat, J., 2004. Comparison of the Holocene and Eemian palaeoenvironments in the South Icelandic Basin: Dinoflagellate cysts as proxies for the North Atlantic surface circulation. Rev. Palaeobot. Palynol. 128, 55-79. https:// doi.org/10.1016/S0034-6667(03)00112-X.

Fink, H.G., Wienberg, C., De Pol-Holz, R., et al., 2013. Cold-water coral growth in the Alboran Sea related to high productivity during the Late Pleistocene and Holocene. Mar. Geol. 339, 71-82.

Fletcher, W.J., 2013. Mid-Holocene emergence of a low-frequency millennial oscillation in western Mediterranean climate: Implications for past dynamics of the North Atlantic atmospheric westerlies. The Holocene 23, 153-166. https://doi.org/10.1177/ 0959683612460783.

Grattepanche, J.-D., Vincent, D., Breton, E., Christaki, U., 2011. Microzooplankton herbivory during the diatom-Phaeocystis spring succession in the eastern English Channel. J. Exp. Mar. Biol. Ecol. 404, 87-97.

Hanquiez, V., 2006. Processus sédimentaires et activité de la Veine d'EauMéditerranéenne au cours du Quaternaire terminal dans leGolfe de Cadix. p. 375.

Hanquiez, V., Mulder, T., Toucanne, S., et al., 2010. The sandy channel-lobe depositional systems in the Gulf of Cadiz: Gravity processes forced by contour current processes. Sediment. Geol. 229, 110-123. https://doi.org/10.1016/j.sedgeo.2009.05.008.

Hansen, P., 1991. Quantitative importance and trophic role of heterotrophic dinoflagellates in a coastal pelagial food web. Mar. Ecol. Prog. Ser. 73, 253-261. https://doi. org/10.3354/meps073253.

Harland, R., 1983. Distribution maps of recent dinoflagellate cysts in bottom sediments from the North Atlantic Ocean and adjacent seas. Palaeontology 26, 321-387.

Heburn, G.W., La Violette, P.E., 1990. Variations in the structure of the anticyclonic gyres found in the Alboran Sea. J. Geophys. Res. 95, 1599. https://doi.org/10.1029/ jc095ic02p01599.

Holzwarth, U., Esper, O., Zonneveld, K., 2007. Distribution of organic-walled dinoflagellate cysts in shelf surface sediments of the Benguela upwelling system in relationship to environmental conditions. Marine Micropaleontology 64, 91-119 https://doi.org/ 10.1016/j.marmicro.2007.04.001.

Kenyon, N., Ivanov, M., Akhmetzhanov, A., Akhmanov, G., 2000. Multidisciplinary study of geological processes on the North East Atlantic and Western Mediterranean Margins. Preliminary results of geological and geophysical investigations during TTR-9 cruise of R/V Professor Logachev, June-July 1999. IOC/UNESCO Tech Ser 56.

Lacombe, H., Lxzeray, J.C., 1959. Sur le regime des eourants clans le détroit de Gibraltar. 248. C.R. Aead. Sei, Paris, pp. 2502-2504.

Landry, M.R., Constantinou, J., Latasa, M., et al., 2000. Biological response to iron fertilization in the eastern equatorial Pacific (IronEx II). III. Dynamics of phytoplankton growth and microzooplankton grazing. Mar. Ecol. Prog. Ser. 201, 57-72. https://doi. org/10.3354/meps201057.

Linstädter, A., Zielhofer, C., 2010. Regional fire history shows abrupt responses of Mediterranean ecosystems to centennial-scale climate change (Olea-Pistacia woodlands, NE Morocco). J. Arid Environ. 74, 101-110.

Louarn, E., Morin, P., 2011. Antarctic intermediate water influence on Mediterranean Sea water outflow. Deep-Sea Res. I Oceanogr. Res. Pap. 58, 932-942.

Machín, F., Hernández-Guerra, A., Pelegrí, J.L., 2006. Mass fluxes in the Canary Basin. Prog. Oceanogr. 70, 416-447. https://doi.org/10.1016/j.pocean.2006.03.019.

Maldonado, A., Nelson, C.H., 1999. Interaction of tectonic and depositional processes that control the evolution of the Iberian Gulf of Cadiz margin. Mar. Geol. 155, 217-242.

Maldonado, A., Somoza, L., Pallarés, L., 1999. The Betic orogen and the Iberian-African boundary in the Gulf of Cadiz: geological evolution (central North Atlantic). Mar. Geol. 155, 9-43. https://doi.org/10.1016/S0025-3227(98)00139-X.

Mantell, G.A., Parkinson, J., Artis, E.T., 1850. A pictorial atlas of fossil remains, consisting of coloured illustrations selected from Parkinson's "Organic remains of a former world," and Artis's “Antediluvian phytology.”. H. G. Bohn, London. 
Marchès, E., Mulder, T., Cremer, M., et al., 2007. Contourite drift construction influenced by capture of Mediterranean Outflow Water deep-sea current by the Portimão submarine canyon (Gulf of Cadiz, South Portugal). Mar. Geol. 242, 247-260. https:// doi.org/10.1016/j.margeo.2007.03.013.

Marret, F., 1994. Distribution of dinoflagellate cysts in recent marine sediments from the east Equatorial Atlantic (Gulf of Guinea). Review of Palaeobotany and Palynology 84, 1-22 https://doi.org/10.1016/0034-6667(94)90038-8.

Marret, F., Zonneveld, K.A.F., 2003a. Figures of dinoflagellate cysts (relative abundance, temperature, salinity and nutrients). Supplement to: Marret, F; Zonneveld, KAF (2003): Atlas of modern organic-walled dinoflagellate cyst distribution. Rev. Palaeobot. Palynol. 125 (1-2), 1-200. https://doi.org/10.1016/S0034-6667(02) 00229-4.

Marret, F., Zonneveld, K.A.F., 2003b. Atlas of modern organic-walled dinoflagellate cyst distribution. Rev. Palaeobot. Palynol. 125, 1-200. https://doi.org/10.1016/s00346667(02)00229-4.

Marret, F., Leroy, S., Chalié, F., Françoise, F., 2004. New organic-walled dinoflagellate cysts from recent sediments of Central Asian seas. Rev. Palaeobot. Palynol. 129, 1-20. https://doi.org/10.1016/j.revpalbo.2003.10.002.

Medialdea, T., Vegas, R., Somoza, L., et al., 2004. Structure and evolution of the "Olistostrome" complex of the Gibraltar Arc in the Gulf of Cádiz (eastern Central Atlantic): Evidence from two long seismic cross-sections. Mar. Geol. 209, 173-198. https://doi.org/10.1016/j.margeo.2004.05.029.

Medialdea, T., Somoza, L., Pinheiro, L.M., et al., 2009. Tectonics and mud volcano development in the Gulf of Cádiz. Mar. Geol. 261, 48-63. https://doi.org/10.1016/j. margeo.2008.10.007.

Morzadec-Kerfourn, M.T., 1984. Les kystes de dinoflagellés dans les sédiments pléistocènes supérieurs et holocènes au large du delta du Rhône et de la Corse. Écologie des microorganismes en Méditerranée occidentale “ECOMED” Pétrole et Techniques. Assoc. Franç. Technic. Pétrol. 303, 170-183.

Morzadec-Kerfourn, M.-T., 1988. Distribution des kystes de dinoflagelles dans les sediments pleistocenes de la marge guineenne de l'Afrique (EQUAMARGE I, 1983). Palaeogeogr. Palaeoclimatol. Palaeoecol. 65, 201-216.

Mulder, T., Lecroart, P., Voisset, M., et al., 2002. The Gulf of Cadiz. A key area for understanding paleoclimate record and oceanic circulation. EOS Trans. Am. Geophys. Union 83, 481-488.

Mulder, T., Voisset, M., Lecroart, P., et al., 2003. The Gulf of Cadiz: An unstable giant contouritic levee. Geo-Mar. Lett. 23, 7-18. https://doi.org/10.1007/s00367-0030119-0.

Nelson, C.H., Baraza, J., Maldonado, A., et al., 1999. Influence of the Atlantic inflow and Mediterranean outflow currents on Late Quaternary sedimentary facies of the Gulf of Cadiz continental margin. Mar. Geol. 155, 99-129. https://doi.org/10.1016/s00253227(98)00143-1.

Ochoa, J., Bray, N.A., 1991. Water mass exchange in the Gulf of Cadiz. Deep Sea Res. Part A Oceanogr. Res. Pap. 38, S465-S503.

Ostenfeld, C.M., 1903. Phytoplankton from the sea around the Faeröes. Bot. Faeröes 2 558-611.

Penaud, A., Eynaud, F., Turon, J., et al., 2008. Interglacial variability (MIS 5 and MIS 7) and dinoflagellate cyst assemblages in the Bay of Biscay (North Atlantic). Mar. Micropaleontol. 68, 136-155. https://doi.org/10.1016/j.marmicro.2008.01.007.

Penaud, A., Eynaud, F. Turon, J.L., et al., 2009. What forced the collapse of European ice sheets during the last two glacial periods (150kaB.P. and 18ka cal B.P.)? Palynological evidence. Palaeogeogr. Palaeoclimatol. Palaeoecol. 281, 66-78. https://doi.org/ 10.1016/j.palaeo.2009.07.012

Pirkenseer, C.M., 2018. Late glacial and Holocene Ostracoda from the Melilla cold-wate coral mound field. Swiss J. Geosci. 111, 549-560. https://doi.org/10.1007/s00015018-0305-8.

Pospelova, V., Pedersen, T.F., de Vernal, A., 2006. Dinoflagellate cysts as indicators of climatic and oceanographic changes during the past $40 \mathrm{kyr}$ in the Santa Barbara Basin, southern California. Paleoceanography 21. https://doi.org/10.1029/ 2005PA001251.

Pospelova, V., de Vernal, A., Pedersen, T.F., 2008. Distribution of dinoflagellate cysts in surface sediments from the northeastern Pacific Ocean $\left(43-25^{\circ} \mathrm{N}\right)$ in relation to seasurface temperature, salinity, productivity and coastal upwelling. Marine Micropaleontology 68, 21-48 https://doi.org/10.1016/j.marmicro.2008.01.008.

Reid PC (1974) Gonyaulacacean dinoflagellate cysts from the British Isles. Nova Hedwig.

Radi, T., de Vernal, A., 2004. Dinocyst distribution in surface sediments from the northeastern Pacific margin $\left(40-60^{\circ} \mathrm{N}\right)$ in relation to hydrographic conditions, productivity and upwelling. Review of Palaeobotany and Palynology 128, 169-193 https://doi.org/ 10.1016/s0034-6667(03)00118-0.

Rochon, A., 1997. Palynologie marine dans le Nord-Est de l'Atlantique Nord: Distribution des kystes de dinoflagellés dans les sédiments récents et changements environnementaux le long des marges sud scandinaves au cours du dernier cycle climatique. Université du Québec à Montréal, Montréal.

Rochon, A., de Vernal, A., Turon, J.-L., et al., 1999. Distribution of recent dinoflagellate cysts in surface sediments from the North Atlantic Ocean and adjacent seas in relation to sea-surface parameters. Am. Assoc. Stratigr. Palynol. Contrib. Ser. 35, 1-146.

Rouis-Zargouni, I., 2010. Évolution paléoclimatique et paléohydrologique de Méditerranée occidentale au cours des derniers 30000 ans: contribution des dinokystes et des foraminifères planctoniques PhD Thesis, Bordeaux 1.

Sangiorgi, F., Capotondi, L., Brinkhuis, H., 2002. A centennial scale organic-walled dinoflagellate cyst record of the last deglaciation in the South Adriatic Sea (Central Mediterranean). Palaeogeogr. Palaeoclimatol. Palaeoecol. 186, 199-216.
Schröder-Ritzrau, A., Frank, N., Fohlmeister, J., et al., 2015. Holocene coral presence across the Strait of Gibraltar MD194 Euro-fleets. In: Van Rooij, D., Hamouni, N., Rüggeberg, A. (Eds.), Late Pleistocene Carbonate Mound Record along the Mediterranean Atlantic Gateway. First MD194 EuroFLEETS Gateways post cruise meeting, 5 May 2015. Faculty of Sciences Rabat, Morocco, pp. 10-11 Programme and Abstract Book.

Sprangers, M., Dammers, N., Brinkhuis, H., et al., 2004. Modern organic-walled dinoflagellate cyst distribution offshore NW Iberia; tracing the upwelling system. Review of Palaeobotany and Palynology 128, 97-106.

Stalder, C., Vertino, A., Rosso, A., et al., 2015. Microfossils, a key to unravel cold-water carbonate mound evolution through time: Evidence from the eastern Alboran Sea. PLoS One 10, e 0140223

Stalder, C., El Kateb, A., Vertino, A., et al., 2018. Large-scale paleoceanographic variations in the western Mediterranean Sea during the last 34,000 years: From enhanced cold-water coral growth to declining mounds. Mar. Micropaleontol. 143, 46-62. https://doi.org/10.1016/j.marmicro.2018.07.007.

Stalder, C., El Kateb, A., Camozzi, O., et al., 2019. Living Benthic Foraminifera from Cold Water Coral Ecosystems in the Melilla Mound Field, Alboran Sea, Western Mediterranean.

Stover, L.E., Evitt, W.R., 1978. Analyses of pre-Pleistocene organic-walled dinoflagellates. Stanford Univ. Publ. Geol. Sci. 15, 1-300.

Susek, E., Zonneveld, K.A., Fischer, G., et al., 2005. Organic-walled dinoflagellate cyst production in relation to upwelling intensity and lithogenic influx in the Cape Blanc region (off north-west Africa). Phycological Research 53, 97-112.

Taylor, F.J.R., Pollingher, U., 1987. Ecology of dinoflagellates, A. General and marine ecosystems. Biol. Dinoflagellates Bot. Monogr. 21, 388-502

Terhzaz, L., 2019. Etude sédimentologique et géochimique des monts carbonatés de la marge marocaine méditerranéenne et de la marge marocaine Nord-Atlantique (Golfe de Cadix),Thèse de doctorat, Faculté des Sciences Rabat. Université Mohammed V 280 p.

Terhzaz, L., Hamoumi, N., Spezzaferri, S., et al., 2018. Carbonate mounds of the Moroccan Mediterranean margin: Facies and environmental controls. Compt. Rendus Geosci. 350, 212-221. https://doi.org/10.1016/j.crte.2018.04.003.

Tesson, M., Gensous, B., 1979. Les sédiments superficiels du plateau continental du Rif Oriental. Mines, Géol. Energ. 46, 117-125.

Titschack, J., Fink, H.G., Baum, D., et al., 2016. Mediterranean cold-water corals-an important regional carbonate factory? Deposit. Rec. 2, 74-96.

Turon, J.-L., 1984. Le palynoplancton dans l'environnement actuel de l'Atlantique nordoriental. Evolution climatique et hydrologique depuis le dernier maximum glaciaire. Mem. Inst. Geol. Bassin Aquit. 17, 1-313.

Turon, J.L., Londeix, L., 1988. Les assemblages de kystes de dinoflagellés en Méditerranée occidentale (Mer d'Alboran). Mise en évidence de l'évolution des paléoenvironnements depuis le dernier maximum glaciaire. Bull. Centres Rech. Explor.-prod. Elf-Aquit. 12, 313-344.

Turon, J.-L., Lézine, A.-M., Denèfle, M., 2003. Land-sea correlations for the last glaciation inferred from a pollen and dinocyst record from the Portuguese margin. Quat. Res. $59,88-96$.

Van Rooij, D., Huvenne, V., Moerkerke, G., 2002. Cruise Report, RV Belgica Cruise 02/12, CADIPOR I (Gulf of Cádiz), Brest - Lissabon - Cádiz, 11.05.-28.05.2002. Renard Centre of Marine Geology (RCMG), University of Ghent, Belgium, p. 30.

Van Rooij, D., Hebbeln, D., Comas, M., et al., 2013. MD194 shipboard scientists. EuroFLEETS cruise summary report "MD194 GATEWAY". Ghent University, Cádiz (ES)-Lisbon (PT) Belgium, p. 214

Vargas-Yáñez, M., Plaza, F., Garcia-Lafuente, J., et al., 2002. About the seasonal variability of the Alboran Sea circulation. J. Mar. Syst. 35, 229-248.

Walker, M., Head, M.J., Berkelhammer, M., et al., 2018. Formal ratification of the subdivision of the Holocene Series/ Epoch (Quaternary System/Period): Two new Global Boundary Stratotype Sections and Points (GSSPs) and three new stages/subseries. Episodes 41, 213-223. https://doi.org/10.18814/epiiugs/2018/018016.

Wall, D., Dale, B., Lohmann, G.P., Smith, W.K., 1977. The environmental and climatic distribution of dinoflagellate cysts in modern marine sediments from regions in the North and South Atlantic Oceans and adjacent seas. Mar. Micropaleontol. 2, 121-200.

Wengler, L., Vernet, J.-L., Ballouche, A., et al., 1992. Signification dee paléomilieux et évolution du climat au Maghreb. Le Maroc oriental au Pléistocène récent. Bull. Soc. Bot. Fr. Actual. Bot. 139, 507-529.

Zapata, L., López-Sáez, J.A., Ruiz-Alonso, M., et al., 2013. Holocene environmental change and human impact in NE Morocco: Palaeobotanical evidence from Ifri Oudadane. The Holocene 23, 1286-1296.

Zitellini, N., Gràcia, E., Matias, L., et al., 2009. The quest for the Africa-Eurasia plate boundary west of the Strait of Gibraltar. Earth Planet. Sci. Lett. 280, 13-50.

Zonneveld, 1997. Dinoflagellate cyst distribution in surface sediments from the Arabian Sea (northwestern Indian Ocean) in relation to temperature and salinity gradients in the upper water column. Deep Sea Research Part II: Topical Studies in Oceanography 44 (6-7), 1411-1443. https://doi.org/10.1016/s0967-0645(97)00007-6.

Zonneveld, K.A., Hoek, R.P., Brinkhuis, H., Willems, H., 2001. Geographical distributions of organic-walled dinoflagellate cysts in surficial sediments of the Benguela upwelling region and their relationship to upper ocean conditions. Prog. Oceanogr. 48, 25-72.

Zonneveld, B.J.M., Grimshaw, J.M., Davis, A.P., 2003. The systematic value of nuclear DNA content in Galanthus. Plant Syst. Evol. 241, 89-102.

Zonneveld, K.A.F., Marret, F., Versteegh, G.J.M., et al., 2013. Atlas of modern dinoflagellate cyst distribution based on 2405 data points. Rev. Palaeobot. Palynol. 191, 1-197. https://doi.org/10.1016/j.revpalbo.2012.08.003. 